\title{
Gene-based association study for lipid traits in diverse cohorts implicates BACE1 and SIDT2 regulation in triglyceride levels
}

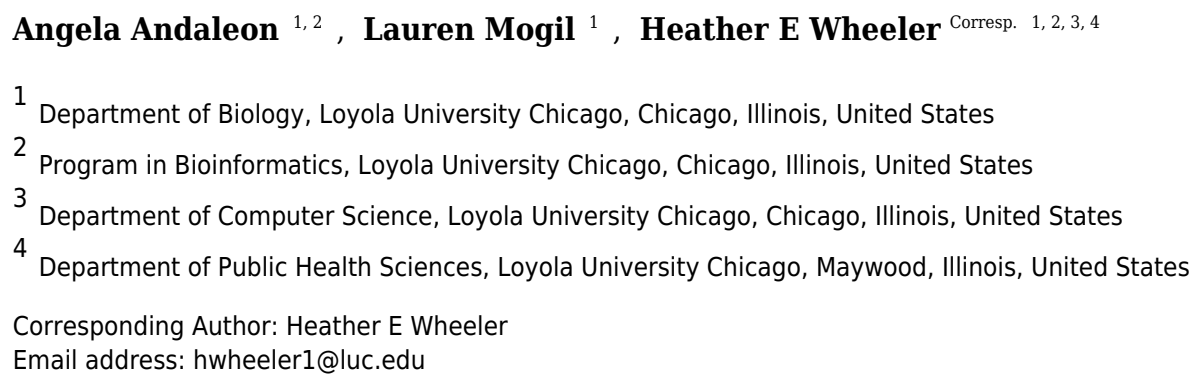

Plasma lipid levels are risk factors for cardiovascular disease, a leading cause of death worldwide. While many studies have been conducted on lipid genetics, they mainly focus on Europeans and thus their transferability to diverse populations is unclear. We performed SNP- and gene-level genome-wide association studies (GWAS) of four lipid traits in cohorts from Nigeria and the Philippines and compared them to the results of larger, predominantly European meta-analyses. Two previously implicated loci met genome-wide significance in our SNP-level GWAS in the Nigerian cohort, rs34065661 in CETP associated with HDL cholesterol $\left(P=9.0 \times 10^{-10}\right)$ and rs1065853 upstream of APOE associated with LDL cholesterol $\left(P=6.6 \times 10^{-9}\right)$. The top SNP in the Filipino cohort associated with triglyceride levels ( $\mathrm{rs662799,} \mathrm{P}=2.7 \times 10^{-16}$ ) and has been previously implicated in other East Asian studies. While this SNP is located directly upstream of well known APOA5, we show it may also be involved in the regulation of BACE1 and SIDT2. Our gene-based association analysis, PrediXcan, revealed decreased expression of BACE1 and decreased expression of SIDT2 in several tissues, all driven by rs662799, significantly associate with increased triglyceride levels in Filipinos (FDR $<0.1$ ). In addition, our PrediXcan analysis implicated gene regulation as the mechanism underlying the associations of many other previously discovered lipid loci. Our novel BACE1 and SIDT2 findings were confirmed using summary statistics from the Global Lipids Genetic Consortium (GLGC) meta-GWAS. 


\section{Gene-Based Association Study for Lipid Traits in Diverse Cohorts Implicates BACE1 and SIDT2 Regulation in Triglyceride Levels}

${ }_{4}$ Angela Andaleon ${ }^{1,2}$, Lauren Mogil ${ }^{1}$, and Heather E. Wheeler ${ }^{1,2,3,4}$

${ }^{1}$ Department of Biology, Loyola University Chicago, Chicago, IL, USA

${ }^{2}$ Program in Bioinformatics, Loyola University Chicago, Chicago, IL, USA

${ }^{3}$ Department of Computer Science, Loyola University Chicago, Chicago, IL, USA

${ }^{4}$ Department of Public Health Sciences, Stritch School of Medicine, Loyola University Chicago, Maywood, IL, USA

Corresponding author:

Heather E. Wheeler ${ }^{1,2,3,4}$

2 Email address: hwheeler1@luc.edu 


\section{ABSTRACT}

Plasma lipid levels are risk factors for cardiovascular disease, a leading cause of death worldwide. While many studies have been conducted on lipid genetics, they mainly focus on Europeans and thus their transferability to diverse populations is unclear. We performed SNP- and gene-level genome-wide association studies (GWAS) of four lipid traits in cohorts from Nigeria and the Philippines and compared them to the results of larger, predominantly European meta-analyses. Two previously implicated loci met genome-wide significance in our SNP-level GWAS in the Nigerian cohort, rs34065661 in CETP associated with HDL cholesterol $\left(P=9.0 \times 10^{-10}\right)$ and rs1065853 upstream of $A P O E$ associated with LDL cholesterol $\left(P=6.6 \times 10^{-9}\right)$. The top SNP in the Filipino cohort associated with triglyceride levels (rs662799, $P=2.7 \times 10^{-16}$ ) and has been previously implicated in other East Asian studies. While this SNP is located directly upstream of well known APOA5, we show it may also be involved in the regulation of BACE1 and SIDT2. Our gene-based association analysis, PrediXcan, revealed decreased expression of BACE1 and decreased expression of SIDT2 in several tissues, all driven by rs662799, significantly associate with increased triglyceride levels in Filipinos (FDR $<0.1$ ). In addition, our PrediXcan analysis implicated gene regulation as the mechanism underlying the associations of many other previously discovered lipid loci. Our novel BACE1 and SIDT2 findings were confirmed using summary statistics from the Global Lipids Genetic Consortium (GLGC) meta-GWAS.

\section{INTRODUCTION}

Though $99.9 \%$ of the genome between humans is identical, millions of variant sites exist in different frequencies between populations, which leads to differences in gene expression and other complex traits (Brown et al., 2016). Since most GWAS have been conducted in European cohorts and most databases are built upon European data, the results may not accurately extrapolate to other global populations, which could lead to disparity within medicine (Bustamante et al., 2011). This discrepancy is alarming considering urgent health issues worldwide, such as obesity and cardiovascular disease. Lipid levels as a complex trait are increasingly concerning due to the growing global rate of obesity caused by the increasing availability of high-fat foods and rapid urbanization (Ellulu et al., 2014). Decreased high density lipoprotein (HDL) cholesterol levels and increased low density lipoprotein (LDL) cholesterol and triglyceride (TRIG) levels are associated with cardiovascular disease, the leading cause of death in the United States (Go et al., 2013). Studies such as the Global Lipids Genetic Consortium (GLGC) acquire information predominantly from Europeans, but lack information from other populations (Coram et al., 2015; Willer et al., 2013). We aim to help remedy this issue by studying lipid traits in diverse populations. We chose two populations with lipid phenotypes available to study from the database of Genotypes and Phenotypes: Yoruba in Ibadan, Nigeria, (Yoruba) and Filipino in Cebu, Philippines (Cebu) (Adair et al., 2011; Wu et al., 2013).

At the time of our study, one of the largest available cholesterol SNP meta-analyses is the GLGC (Willer et al., 2013). The cohort in that study consists of 188,577 European-ancestry individuals and 7,898 non-European-ancestry individuals. 157 loci were found to be significantly associated with total cholesterol (CHOL), HDL, TRIG, or LDL levels, and they conducted further gene set enrichment analysis with MAGENTA (Ayellet et al., 2010). However, gene-level association studies that integrate transcriptome data, like PrediXcan and TWAS, were not performed (Gamazon et al., 
2015; Gusev et al., 2016). Summary statistics from GLGC were used as a replication and base set in our analyses of the Yoruba and Cebu cohorts.

Both the Cebu and Yoruba cohorts have been used in genetic studies of lipids previously (Hall et al., 2006; Wu et al., 2013). These studies, both using the same data we study here, focused on APOE, a well-known gene that is associated with lipid levels and Alzheimer's disease (Middelberg et al., 2011). Previously, SNP-level GWAS in the Cebu and other East Asian cohorts attributed rs662799 as affecting function of APOA5, which is located 571 bases upstream (Wu et al., 2013; Lu et al., 2016; Spracklen et al., 2017). Beyond the APOE candidate gene study, no full GWAS has been conducted in the Yoruba cohort.

In this study, we performed a genome wide association study (GWAS) in each population using linear mixed modeling (Zhou and Stephens, 2012) and a conditional and joint analysis (Yang et al., 2012). Subsequently, we calculated the genetic correlation for each lipid trait between the populations at the SNP-level using bivariate REML analysis (Yang et al., 2011). We also used cross-population empirical Bayes (XPEB) modeling to improve power to detect SNPs with similar effects as previously found in larger European meta-analyses (Coram et al., 2015). Finally, we used the transcriptome-informed method PrediXcan to implicate genes in CHOL, HDL, LDL, and TRIG (Gamazon et al., 2015). Using our data and those from previous European studies, we confirm previously known loci and implicate new loci through the mechanism of gene expression regulation in Filipinos (Willer et al., 2013). Our gene-based association study for triglyceride levels in the Cebu cohort suggests that rs662799 may affect the expression of BACE1 and SIDT2 rather than that of APOA5.

\section{MATERIALS AND METHODS}

\begin{tabular}{c|c|c} 
& Yoruba & Cebu \\
\hline Accession number & phs000378.v1.p1 & phs000523.v1.p1 \\
Type of genotyping & Whole genome genotyping & Whole genome genotyping \\
Source platform & Illumina, HumanOmni2.5 & Affymetrix, Genomewide \\
& Human SNP Array 5.0 \\
Pre-QC SNPs & $2,443,179$ & 440,792 \\
Pre-QC individuals & 1,251 & 1,799 \\
Post-QC SNPs & $1,522,836$ & 369,185 \\
Post-QC individuals & 1,017 & 1,765 \\
Post-imputation GWAS SNPs & $12,553,142$ & $4,496,603$
\end{tabular}

Table 1. Data analyzed

\section{Cohorts}

We obtained data from both cohorts through the database of Genotypes and Phenotypes with Institutional Review Board approval (Mailman et al., 2007) (Table 1). Yoruba consists of 1,251 adults of Yoruba ethnicity age 73 to 103 years old, living in Ibadan, Nigeria in 2001, who were originally studied in the Indianapolis Ibadan Epidemiological Study of Dementia (Ogunniyi et al., 1997). The Cebu population consists of 1,799 Filipino mothers, who gave birth between May 1 , 
1983 and April 30, 1984 in the metropolitan area of Cebu, Philippines. This cohort was originally studied in the Cebu Longitudinal Health and Nutrition Survey (Adair et al., 2011), and at the time of data collection in 2005, the mothers were age 34 to 70. The Yoruba cohort was genotyped with the Illumina HumanOmni2.5 array and the Cebu cohort was genotyped with the Affymetrix Genomewide Human SNP Array 5.0. Both cohorts had CHOL, HDL, LDL, and TRIG levels measured after fasting $(\mathrm{mg} / \mathrm{dL}$ ) and we subsequently rank normalized each trait (Aulchenko et al., 2007) (Supplemental Table 2). See https://github.com/aandaleon/px_chol for all scripts used in our analyses.

Summary statistics from the Global Lipids Genetic Consortium meta-analysis (Willer et al., 2013) were downloaded from/http://csg.sph.umich.edu/abecasis/public/lipids2013/. Though the offspring of the Cebu cohort are included in the GLGC cohort, they form a small portion of the dataset $(1,771 / 188,577)$ and thus do not drive the signal for the entire dataset.

\section{Quality Control}

We performed quality control on the genotypes in these cohorts with PLINK following a standard quality control pipeline (Turner et al., 2001; Purcell et al., 2007). Starting with the dbGaP PLINK binary files, we removed SNPs with call rates $<99 \%$ in the individual populations. Subsequently, SMARTPCA within Eigensoft was used to map individuals on their first 10 principal components, and individuals with excess ( \pm 5 standard deviations) from the population mean on the first two components were removed (Patterson et al., 2006) (Supplemental Figures 1 and 2). This was followed by removing individuals with excess heterozygosity ( \pm 3 standard deviations), leaving the Yoruba cohort with 1,017 individuals with genotype and lipid phenotype data, including $1,522,836$ SNPs. The Cebu cohort retained 1,757 individuals with genotype and lipid phenotype data, including 369,185 SNPs. Both cohorts were mapped to hg19, which included performing a liftover in the Cebu cohort from hg18 to hg19. We used an imputation preparation tool on the Cebu cohort available at http://www.well.ox.ac.uk/ wrayner/tools/that adjusted the data by matching the strand, alleles, position, ref/alt assignments, and frequency differences to the $1000 \mathrm{G}$ reference panel.

\section{Imputation}

Yoruba SNPs were imputed on the Sanger Imputation Server with EAGLE2 and PBWT using the African Genomes Reference Panel to improve genome coverage (Delaneau et al., 2012; Durbin, 2014; McCarthy et al., 2016). We imputed the Cebu SNPs using the Michigan Imputation Server with the 1000 Genomes phase 3 reference panel and EAGLE2 (Auton et al., 2015; Das et al., 2016; Loh et al. 2016). The output from the imputation was filtered to remove SNPs with $R^{2}<0.8$ and minor allele frequency $<0.01$, leaving 12,553,142 SNPs for analysis in Yoruba and 4,496,603 SNPs for analysis in Cebu.

\section{SNP-level Genome-Wide Association Study}

The imputed genotype dosages were used in a genome-wide association study performed with Genome-Wide Efficient Mixed Model Analysis (GEMMA) software using a univariate linear mixed model for each of the four phenotypes (Zhou and Stephens, 2012). SNPs with $\mathrm{P}<5 \times 10^{-8}$ using the Wald test were considered genome-wide significant. The top SNPs from the GEMMA analysis were plotted using LocusZoom to depict their proximity to various genes (Pruim et al., 2011). For each phenotype tested, we also used GEMMA to obtain the percent variance explained (PVE) by all 
the SNPs, i.e. the "chip heritability" (Zhou and Stephens, 2012). Conditional and joint analyses were then performed using GCTA-COJO (Yang et al., 2011, 2012) to identify the lead SNP or SNPs at each locus.

\section{Comparison of Populations}

Both populations' GEMMA results and summary statistics from GLGC (Willer et al., 2013) were used in a cross-population empirical Bayes model (XPEB) to compute false discovery rates for each SNP, with significance declared at FDR $<0.05$. This model improves efficiency in GWAS by incorporating relevant results from larger (ex. GLGC) GWAS only when there are similar effect sizes between populations (Coram et al., 2015). Sample sizes in the GLGC results ranged from 50,000 to 187,365 depending on the SNP. Because XPEB assumes similar sample size in the base population across SNPs, we ran XPEB using only the SNPs with sample size between 80,000 and 95,000 in GLGC, which left us with 4,454,201 markers for each phenotype. SNP-level comparisons between populations were performed using Genome-wide Complex Trait Analysis (GCTA) software (Yang et al., 2011). We performed a bivariate restricted maximum likelihood (REML) analysis to estimate the genetic correlation between the Cebu and Yoruba cohorts for each phenotype (Lee et al., 2012).

\section{Gene-Based Association Study}

PrediXcan, the gene-level association study, was performed using models built with cis-expression quantitative trait loci results from the Genotype-Tissue Expression Project (GTEx) (Ardlie et al., 2015; Wheeler et al., 2016; Barbeira et al., 2017). GTEx models (GTEx-V6p-HapMap-2016-09-08.tar.gz) were downloaded from PredictDB at http://predictdb.hakyimlab.org/. Significance for each tissue was determined as FDR $<0.1$ across all testable genes in all tissues $(\mathrm{N}=198,970)$. In total, 44 GTEx models were tested in both cohorts (Table 2). Predicted expression levels were obtained and tested for association with the lipid phenotypes using PrediXcan software (Gamazon et al., 2015). Significant genes were further plotted using ggplot to depict the predicted gene expression against the observed phenotype (Wickham et al., 2016). For the replication cohort, GLGC, Summary-PrediXcan (Barbeira et al., 2017) was used because only summary statistics were available.

\section{Backward Elimination Modeling}

Because our PrediXcan analysis showed multiple genes associated with TRIG at the 11q23.3 locus in Cebu, we conducted a backward elimination analysis to determine the lead gene or genes. We used the $\mathrm{R}$ Im function to build all multiple linear regression models. The starting model included predicted expression terms for all genes with rs662799 or a linked SNP $\left(r^{2}>0.6\right)$ in its predictive model and the absolute value of the marginal t-statistic greater than 3 . The term with the highest $\mathrm{P}$-value was eliminated and the model rerun until only terms with $P<0.05$ remained in the model.

\section{RESULTS}

\section{Yoruba SNP-level GWAS}

We sought to better understand the genetic architecture of lipid traits within and across populations. In the Yoruba cohort from Ibadan, Nigeria, which included 1,017 individuals and 


\begin{tabular}{|c|c|c|c|c|c|}
\hline Tissue model & $\begin{array}{l}\text { Tissue } \\
\text { abbreviation }\end{array}$ & $\begin{array}{l}\text { Genes } \\
\text { tested }\end{array}$ & Tissue model & $\begin{array}{l}\text { Tissue } \\
\text { abbreviation }\end{array}$ & $\begin{array}{l}\text { Genes } \\
\text { tested }\end{array}$ \\
\hline Adipose - Subcutaneous & ADPSBQ & 7,254 & Esophagus - Mucosa & ESPMCS & 7,710 \\
\hline $\begin{array}{l}\text { Adipose - Visceral } \\
\text { (Omentum) }\end{array}$ & ADPVSC & 4,447 & Esophagus - Muscularis & ESPMSL & 6,338 \\
\hline Adrenal Gland & ADRNLG & 3,785 & Heart - Atrial Appendage & HRTAA & 4,450 \\
\hline Artery - Aorta & ARTAORT & 5,943 & Heart - Left Ventricle & HRTLV & 4,718 \\
\hline Artery - Coronary & ARTCRN & 3,141 & Liver & LIVER & 2,502 \\
\hline Artery - Tibial & ARTTBL & 7,074 & Lung & LUNG & 6,448 \\
\hline $\begin{array}{l}\text { Brain - Anterior cingulate } \\
\text { cortex (BA24) }\end{array}$ & BRNACC & 2,430 & Muscle - Skeletal & MSCLSK & 6,520 \\
\hline $\begin{array}{l}\text { Brain - Caudate (basal } \\
\text { ganglia) }\end{array}$ & BRNCDT & 3,325 & Nerve - Tibial & NERVET & 8,016 \\
\hline $\begin{array}{l}\text { Brain - Cerebellar } \\
\text { hemisphere }\end{array}$ & BRNCHB & 4,077 & Ovary & OVARY & 2,673 \\
\hline Brain - Cerebellum & BRNCHA & 5,066 & Pancreas & PNCREAS & 4,603 \\
\hline Brain - Cortex & BRNCTXA & 3,334 & Pituitary & PTTARY & 3,094 \\
\hline $\begin{array}{l}\text { Brain - Frontal Cortex } \\
\text { (BA9) }\end{array}$ & BRNCTXB & 3,138 & Prostate & PRSTTE & 2,491 \\
\hline Brain - Hippocampus & BRNHPP & 2,508 & $\begin{array}{l}\text { Skin - Not Sun Exposed } \\
\text { (Suprapubic) }\end{array}$ & SKINNS & 5,471 \\
\hline Brain - Hypothalamus & BRNHPT & 2,290 & $\begin{array}{l}\text { Skin - Sun Exposed } \\
\text { (Lower leg) }\end{array}$ & SKINS & 7,665 \\
\hline $\begin{array}{l}\text { Brain - Nucleus } \\
\text { accumbens (basal ganglia) }\end{array}$ & BRNNCC & 2,984 & $\begin{array}{l}\text { Small Intestine - Terminal } \\
\text { Ileum }\end{array}$ & SNTTRM & 2,515 \\
\hline $\begin{array}{l}\text { Brain - Putamen (basal } \\
\text { ganglia) }\end{array}$ & BRNPTM & 2,621 & Spleen & SPLEEN & 3,602 \\
\hline Breast - Mammary Tissue & BREAST & 4,473 & Stomach & STMACH & 4,035 \\
\hline $\begin{array}{l}\text { Cells - EBV-transformed } \\
\text { lymphocytes }\end{array}$ & LCL & 3,441 & Testis & TESTIS & 7,002 \\
\hline $\begin{array}{l}\text { Cells - Transformed } \\
\text { fibroblasts }\end{array}$ & FIBRBLS & 7,543 & Thyroid & THYROID & 7,853 \\
\hline Colon - Sigmoid & CLNSGM & 3,619 & Uterus & UTERUS & 2,058 \\
\hline Colon - Transverse & CLNTRN & 4,729 & Vagina & VAGINA & 1,939 \\
\hline $\begin{array}{l}\text { Esophagus - } \\
\text { Gastroesophageal } \\
\text { Junction }\end{array}$ & ESPGEJ & 3,457 & Whole Blood & WHLBLD & 6,588 \\
\hline
\end{tabular}

Table 2. The number of genes tested in PrediXcan using expression prediction models built in GTEx Project tissues. Genes tested had a cross-validated prediction performance $R^{2}>0.01$. 
12,553,142 SNPs, we conducted SNP-level GWAS for four lipid traits CHOL, HDL, LDL, and TRIG. For each lipid trait, we used a univariate linear mixed model, which accounts for relatedness within the populations (Zhou and Stephens, 2012). This was especially important because one-third of the Yoruba cohort is related to at least one other member (proportion identity by descent $>$ 0.125). Across the four phenotypes, five SNPs surpassed the genome-wide significance threshold of $P<5 \times 10^{-8}$ at two loci (Figure 1). Conditional and joint analysis (Yang et al., 2011, 2012) did not reveal additional associated SNPs at these two loci and the top hits are shown in Table 3 . rs34065661 is on chromosome 16q13 within an intron of CETP and rs 1065853 is on chromosome 19q13.32 near APOE (Figure 1). Both CETP and APOE are well-known and well-studied lipid genes (Buyske et al., 2012; Rasmussen-Torvik et al., 2012).

\section{Cebu SNP-level GWAS}

We performed SNP-level GWAS for the same four lipid phenotypes in 1,765 individuals from Cebu, Philippines, using 4.5 million imputed SNPs (see Methods). No SNPs met genome-wide significance for the CHOL, HDL, and LDL phenotypes. However, 44 SNPs were genome-wide significant $\left(P<5 \times 10^{-8}\right)$ for TRIG and all grouped on chromosome 11q23.3 (Figure 2), a locus that includes various lipid genes such as APOA1 and APOA4. The most significant SNP in this group is rs662799, with a marginal $\mathrm{P}=2.7 \times 10^{-16}$. It is located 571 base pairs upstream of $A P O A 5$, and has been previously associated with cholesterol traits in Asian populations, possibly due to its high minor allele frequency within Asian populations, with MAF for minor allele G at 0.245 in 1000 Genomes EAS compared to 0.083 in EUR (Hall et al., 2006) (Figure 3). Conditional and joint analysis (Yang et al., 2011, 2012) did not reveal additional associated SNPs at the 11q23.3 locus, but did reveal an additional genome-wide significant SNP on chromosome 2 in the GCKR gene (Table 3). As a positive control, we compared the results from the previous Cebu GWAS Wu et al. (2013) and our GWAS and obtained largely the same significant results (Supplemental Table 1).

\section{Integrating larger European study results into Yoruba and Cebu SNP-level GWAS}

The overlapping genetic architecture between populations for most traits is likely nonzero, but not $100 \%$ either due to differences in allele frequencies, effect sizes, and linkage disequilibrium patterns. Currently, European GWAS often have sample sizes 100 times larger than non-European studies. However, studies in diverse populations are growing (Spracklen et al., 2017, Wojcik et al., 2017). Traditional meta-analysis methods give the most weight to the GWAS with the largest sample size. Therefore, meta-analyses combining populations by traditional methods would be driven by the European results, drowning out any additional signal. The cross-population empirical Bayes (XPEB) method is designed to boost signal in a target (small, usually non-European) population whenever the base (large, usually European) population shares genetic architecture, but does not generate false positives when the signal is only present in the base population (Coram et al. 2015).

We used XPEB to improve power for mapping lipid traits in the Yoruba and Cebu cohorts by integrating results from the base population GLGC, a large lipid meta-analysis of European individuals (Willer et al., 2013). In XPEB, we input the SNPs and P-values from both our target GWAS (Yoruba or Cebu) and the base European GWAS. The output includes a population-wide estimate of the degree of genetic architecture overlap, $\kappa_{1}$, and a new false discovery rate (FDR) for each individual SNP in common between the base and target GWAS.

In the Yoruba population, we found associated loci (FDR $<0.05$ ) using XPEB for the CHOL, HDL, and LDL phenotypes (Supplemental Table 3). These results reflect the estimated architecture 


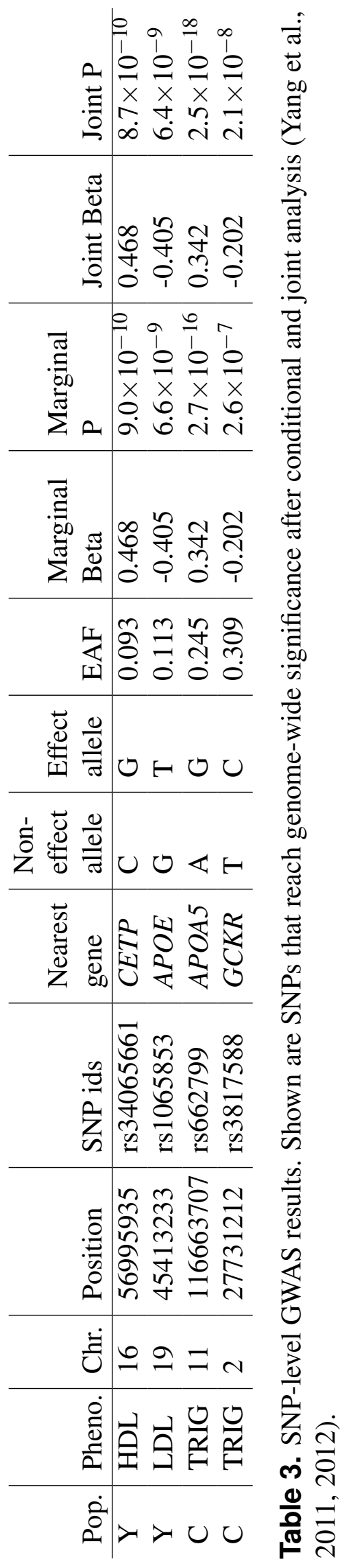



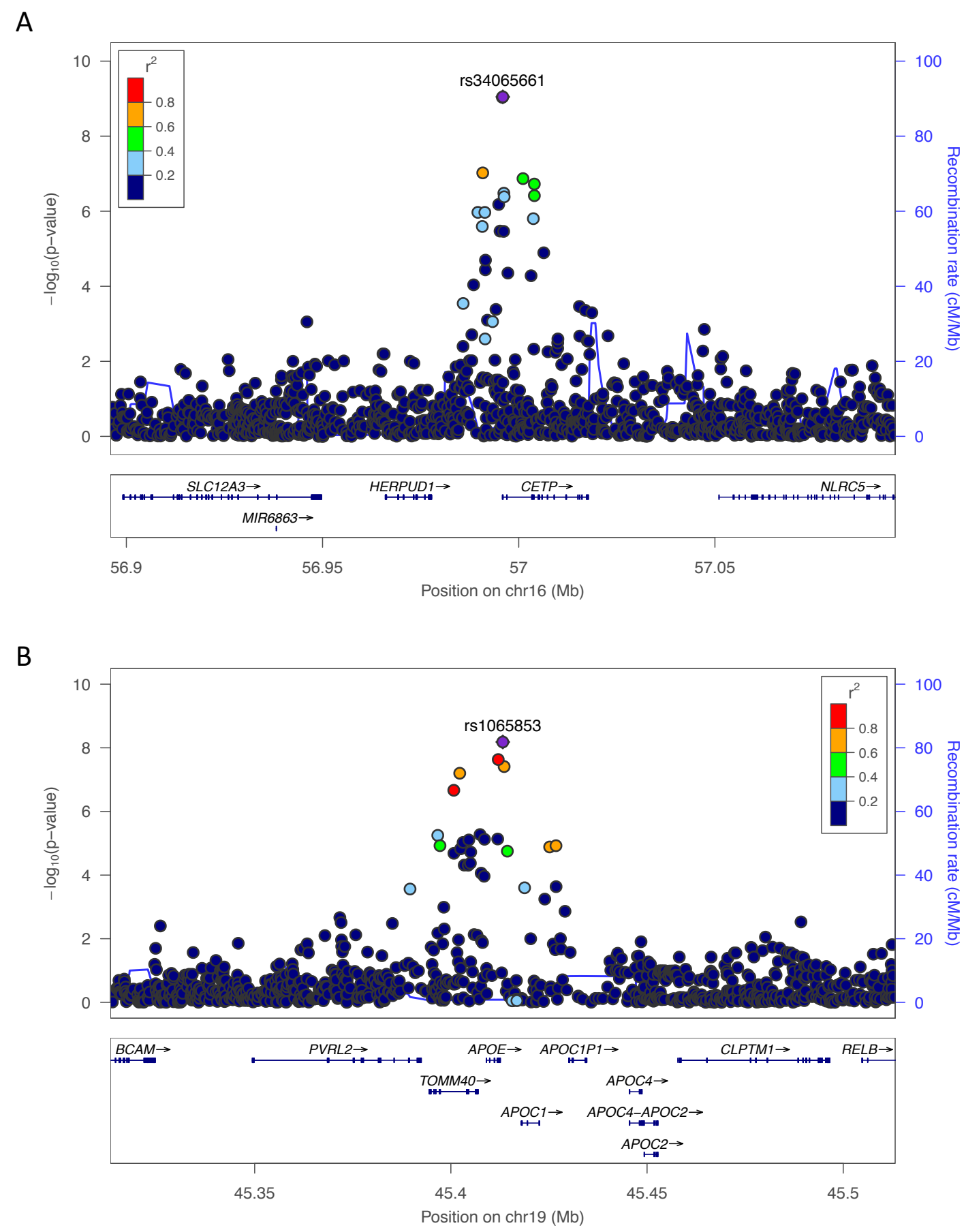

Figure 1. LocusZoom plots of the most significant SNPs in (A) HDL (rs34065661) and (B) LDL (rs1065853) in Yoruba. The color of each dot represents the SNP's linkage disequilibrium $r^{2}$ with the labeled SNP in the 1000 Genomes African populations. 


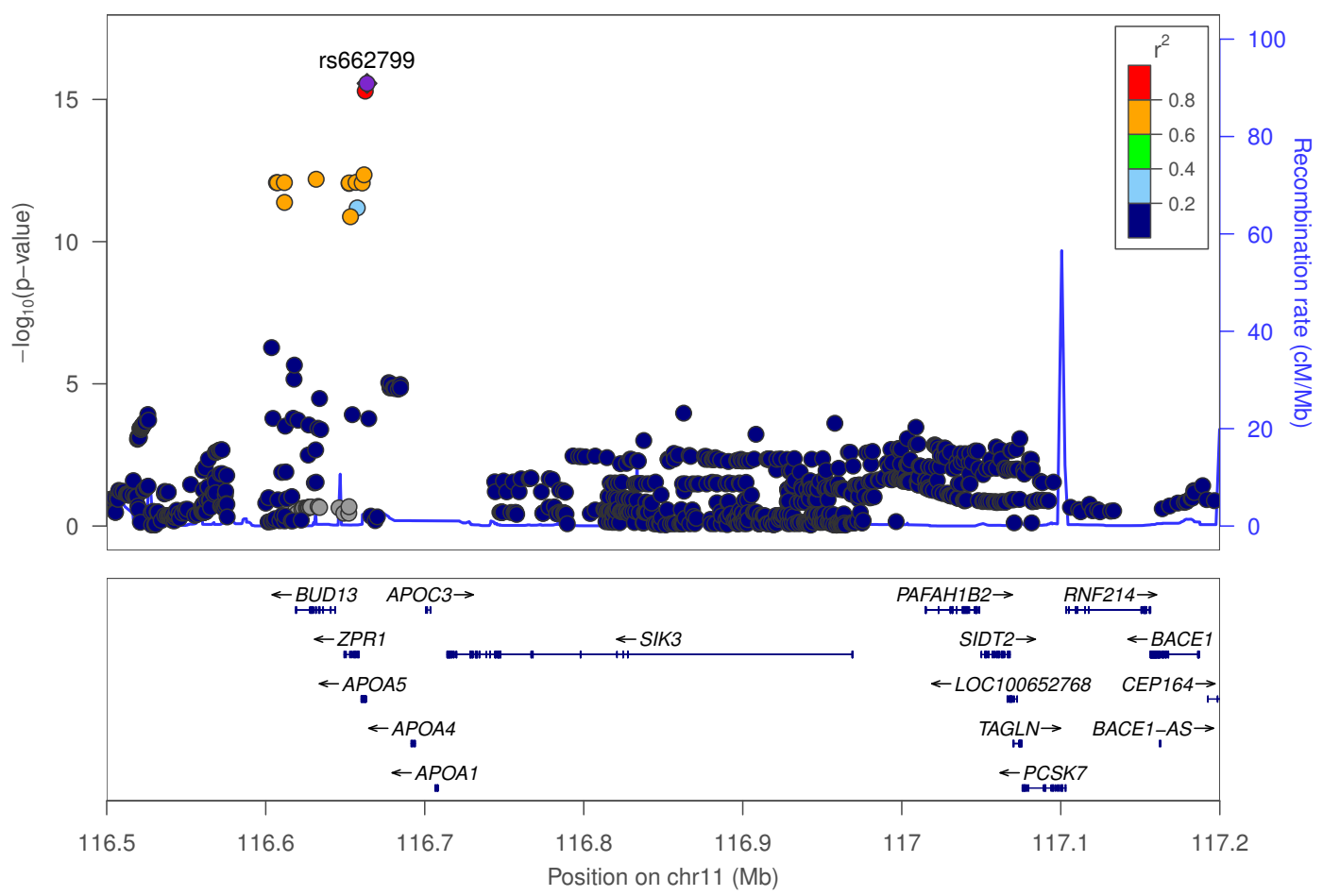

Figure 2. The top Cebu GWAS signal, rs662799, which associated with TRIG levels and is $571 \mathrm{bp}$ upstream of APOA5. The color of each dot represents the SNP's linkage disequilibrium $r^{2}$ with rs662799 in the 1000 Genomes East Asian populations.

\section{chr11:116663707 G/A}

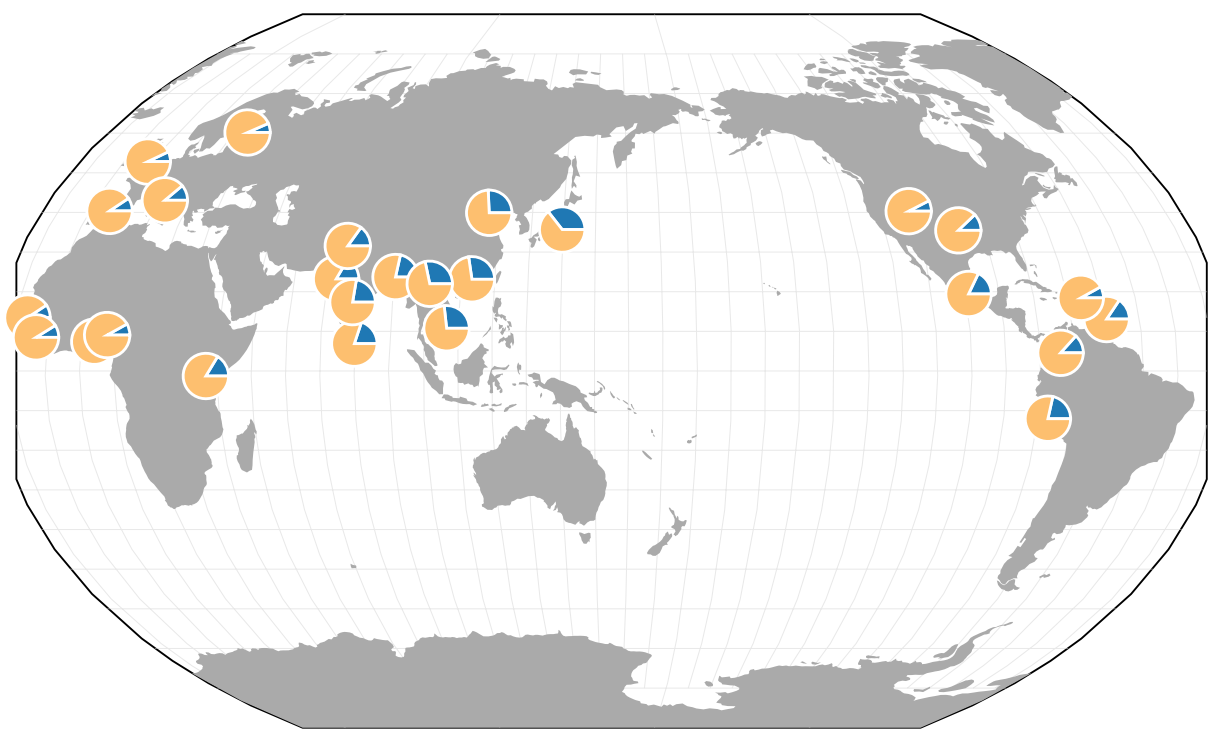

Figure 3. Allele frequencies of TRIG associated SNP and driver of predicted expression models in multiple genes, rs662799, in 1000 Genome populations. Figure generated with the Geography of Genetic Variants Browser (Marcus and Novembre, 2016). 
overlap with GLGC, where $\kappa_{1}$ was 0.65 for CHOL, 0.51 for HDL, 0.9 for LDL, and 0 for TRIG. The CETP locus, which was also significant in the Yoruba-only HDL GWAS was the most significant result in the XPEB analysis. In addition, several other previously implicated genes were significant in the XPEB analysis, including LDLR for CHOL and PCSK9, LPA, and SMARCA4 for LDL (Wu et al. 2013; Willer et al., 2013; Surakka et al., 2014).

In Cebu, CHOL, TRIG, and LDL each had $\kappa_{1}=0.90$, while HDL had $\kappa 1=0.64$. Tens or hundreds of SNPs had FDR $<0.05$ for each phenotype, including those found in the Cebu-only GWAS (Table 3). Additional significant SNPs located within or near other well-known, previously studied lipid genes included CETP and LIPC in HDL; PLCG1 and TOPI in LDL; and APOA5 and BUD13 in TRIG (Asselbergs et al., 2012; Spracklen et al., 2017; Wu et al., 2013; Zhou et al., 2013; Kim et al., 2011) (Supplemental Table 4).

\section{Heritability}

\begin{tabular}{c|c|c|c} 
& Yoruba $(\mathrm{n}=1,017)$ & Cebu $(\mathrm{n}=1,765)$ & European $(\mathrm{n}=5,123)^{*}$ \\
\hline CHOL & $0.040 \pm 0.061$ & $0.067 \pm 0.093$ & $0.29 \pm 0.043$ \\
HDL & $0.013 \pm 0.037$ & $0.217 \pm 0.091$ & $0.34 \pm 0.043$ \\
TRIG & $0.049 \pm 0.110$ & $0.140 \pm 0.103$ & $0.38 \pm 0.041$ \\
LDL & $0.029 \pm 0.046$ & $0 \pm 0.096$ & $0.19 \pm 0.047$
\end{tabular}

Table 4. Percent variance explained (PVE) and standard error as estimated in GEMMA for each trait compared.

$$
\text { * from Sabatti et al. (2009); Zhou (2017) }
$$

As part of our GWAS study, we also estimated the percent variance explained (PVE) by all SNPs tested, i.e. "chip heritability", using GEMMA and conducted further genetic correlation analysis using GCTA (Yang et al., 2011; Zhou and Stephens, 2012). By estimating heritability, we can help determine which portion of our phenotype is not explained through our analyses and is influenced by other factors, such as diet.

In the Yoruba cohort, no PVE estimate was significantly different than zero. All PVE estimates for Yoruba were low when compared to variance component studies in a Finnish cohort of 5,123 individuals (Sabatti et al., 2009; Zhou, 2017). Unlike in Yoruba, PVE estimates for two phenotypes, HDL and TRIG, within the Cebu were significantly different than zero and closer to the Finnish estimates (Table 4).

We attempted to estimate the genetic correlation between all SNPs in the Cebu and Yoruba populations using bivariate REML analysis as implemented in GCTA (Lee et al., 2012). The only phenotype that converged was TRIG, with an estimated correlation of $0.644 \pm 0.65$, indicating there is shared architecture between the populations. However, the small sample sizes available in our study do not offer enough power to reliably estimate heritability and genetic correlation as indicated by the large standard errors.

\section{Yoruba Gene-Based Association Study}

While many GWAS have been performed on lipid traits, most of the significant SNPs found fall outside of protein coding regions and thus their mechanisms of action are not immediately apparent. PrediXcan is a gene-level association method that incorporates functional data on potential regulatory elements to provide mechanistic directionality for association of a gene with a 


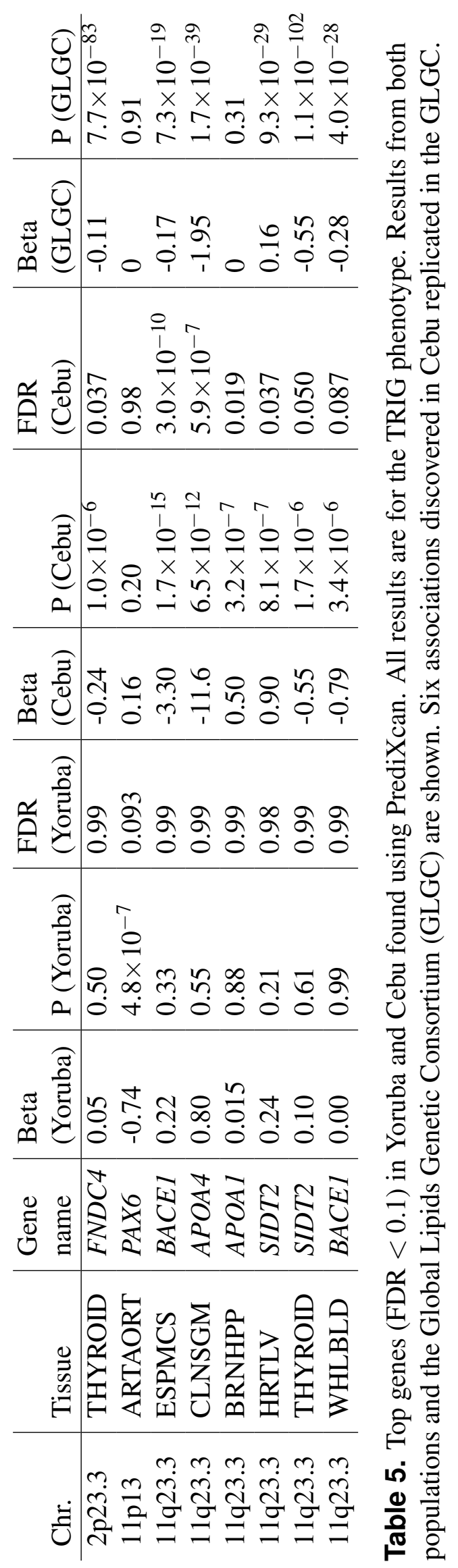


phenotype (Gamazon et al., 2015). PrediXcan uses gene expression prediction models built from genome-transcriptome datasets such as the Genotype-Tissue Expression (GTEx) Project to predict gene expression from genotype and then tests the predicted expression levels for association with with trait of interest (Ardlie et al., 2015). We applied PrediXcan to our SNP-level GWAS results using models built in 44 GTEx tissues (Barbeira et al., 2017) (Table 2).

For each tissue, we declared associations significant if FDR $<0.1$, across all genes and tissues tested, to adjust for multiple testing. Of the four phenotypes for this cohort and 44 tissues with models available, one gene, PAX6, surpassed the significance threshold. PAX6 was not significant in Cebu or GLGC (Table 5). In humans, PAX6 has been associated with insulin production (Ahlqvist et al. 2012). Currently, there is little known about PAX6 and its potential association with lipid or cardiovascular phenotypes.

\section{Cebu Gene-Based Association Study}

When we applied PrediXcan to the Cebu cohort, 7 genes were found significant (Table 5). A few of these genes, such as FNDC4, APOA1 and APOA4, are well-documented in lipid traits, while genes such as SIDT2 have been previously implicated in Asians (Teslovich et al., 2010; Kim et al., 2011; Willer et al., 2013; Wu et al., 2013; Zhou et al., 2013; Gombojav et al., 2015; Lu et al., 2016; Spracklen et al., 2017). The association of $B A C E 1$ with TRIG was highly significant (FDR = $3.02 \times 10^{-10}$, Figure 4 ). The predicted increase in BACE1 expression and decrease in TRIG levels is an association not previously seen in humans, but has been observed in mice (Meakin et al., 2012; Baek et al., 2016) (Figure 5). Additionally, SIDT2 has a similar effect across many tissue models, indicating its potential importance in regulating TRIG levels as well (Figures 5, 6). Both BACE1 and SIDT2 have increased gene expression associated with decreased TRIG levels in most tissues and share many SNPs in most of their prediction models.

We conducted a backward elimination analysis to determine the lead gene or genes at the 11q23.3 locus. The starting model include all gene-tissue combinations in Figure 6, which includes all genes with rs662799 or a linked SNP $\left(r^{2}>0.6\right)$ in its predictive model and $|t|>3$, where $t$ is the association test statistic. The most significant gene in the final model was ESPMCS-BACE1 $\left(P=1 \times 10^{-10}\right)$, with residual effects present $(P<0.05)$ for LCL-SIDT2, MSCLSK-APOA1, TESTIS-CEP164, and WHLBLD-BACE1 (Table 6).

\begin{tabular}{l|l|l|l|l|l} 
& & & Std. & & \\
Tissue & Gene & Estimate & Error & $\mathrm{t}$ value & $\mathrm{P}$ \\
\hline ESPMCS & BACE1 & -3.7 & 0.57 & -6.4 & $1.7 \times 10^{-10}$ \\
LCL & SIDT2 & -0.20 & 0.06 & -3.2 & 0.001 \\
MSCLSK & APOA1 & 1.5 & 0.52 & 2.9 & 0.003 \\
TESTIS & CEP164 & -0.17 & 0.08 & -2.2 & 0.025 \\
WHLBLD & BACE1 & 0.83 & 0.29 & 2.9 & 0.003
\end{tabular}

Table 6. Gene-tissue combinations from Figure 6 with $P<0.05$ in a backwards-elimination linear model including the TRIG phenotype and predicted gene expression terms.

\section{Comparing populations}

In a direct comparison of the significant genes obtained through PrediXcan for the Cebu and Yoruba cohorts, there is no gene that shares significance $($ FDR $<0.05)$ between populations (Table 
A

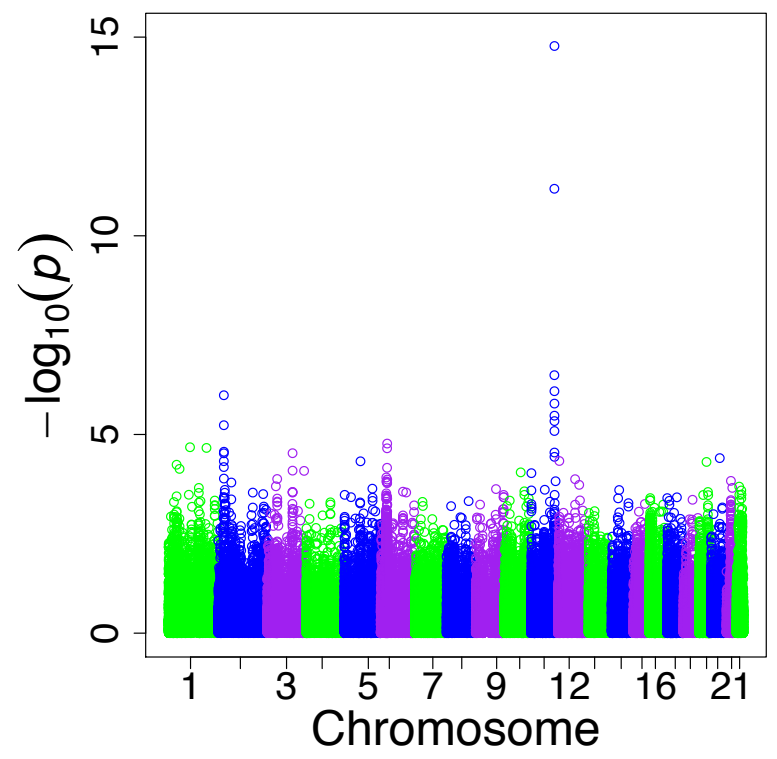

B

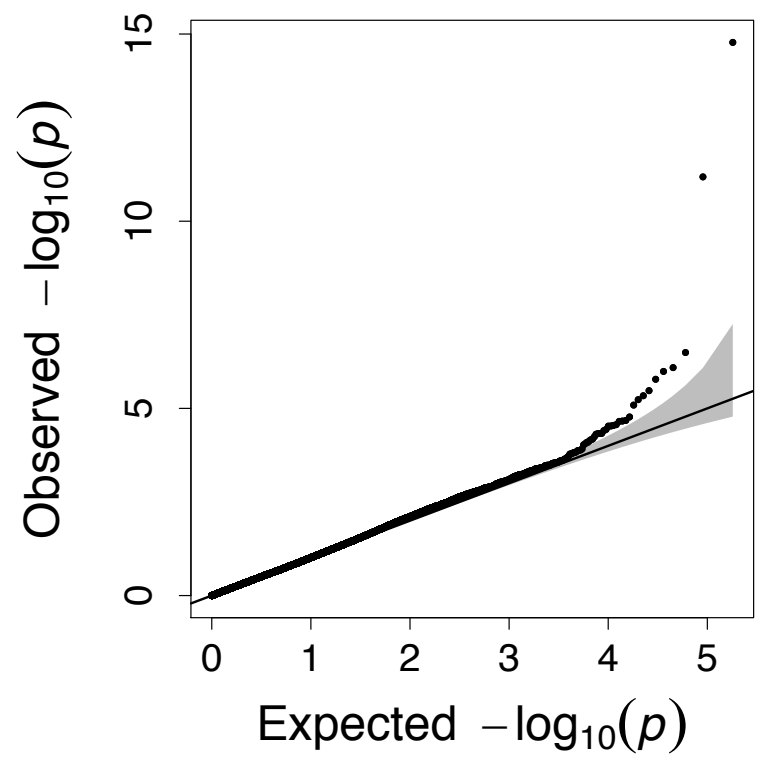

Figure 4. PrediXcan results for the Cebu TRIG phenotype using gene expression models built in ESPMCS tissue. (A) Manhattan plot: $-\log _{10}$ P-values are plotted against the respective chromosomal position of each gene across all tissues. (B) QQ plot of observed versus expected $-\log _{10}$ P-values for each gene across all tissues.
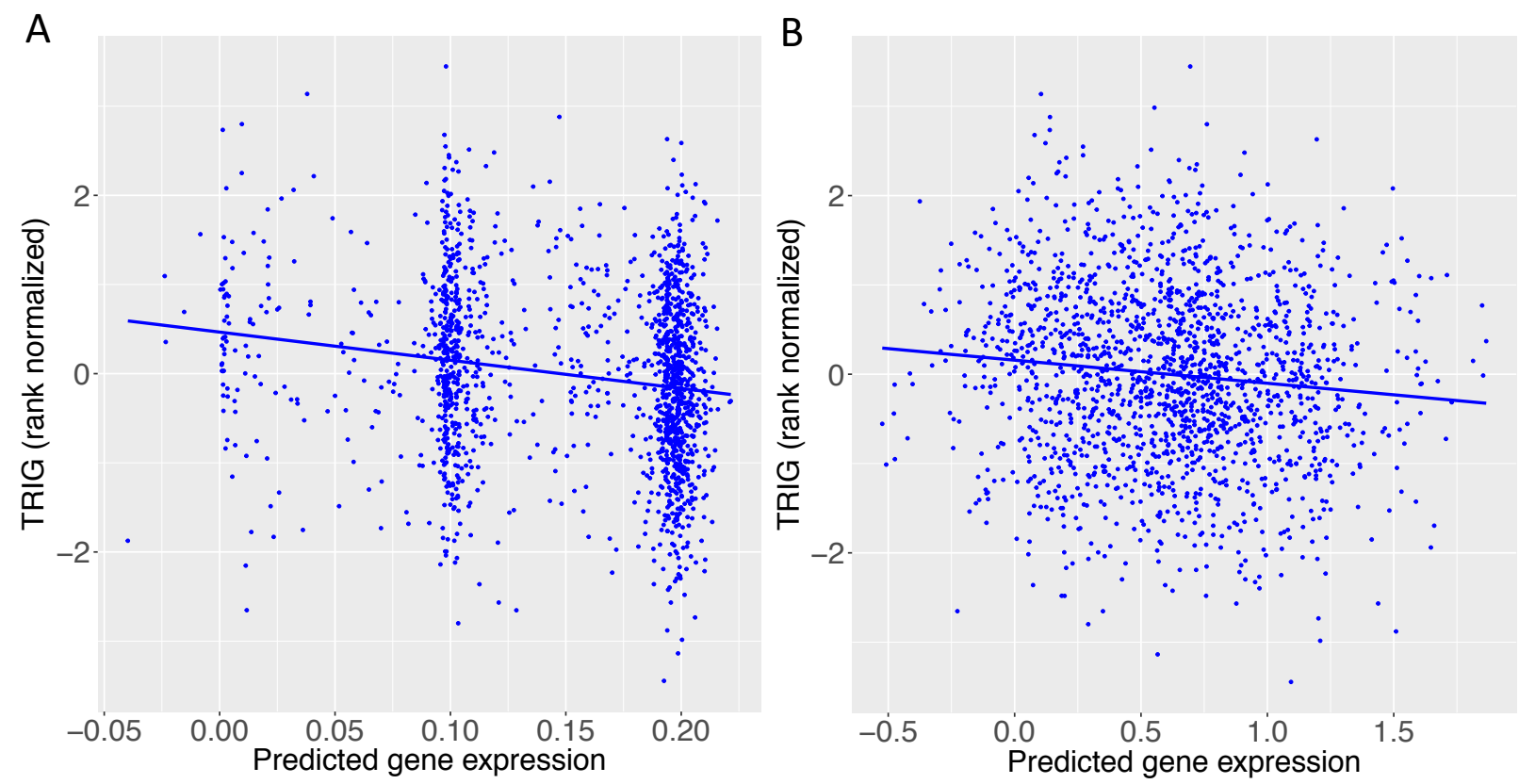

Figure 5. TRIG levels vs. predicted expression of two genes in Cebu (A) BACE1 predicted expression using the GTEx ESPMCS prediction model. (B) SIDT2 predicted expression using the GTEx LCL prediction model. 


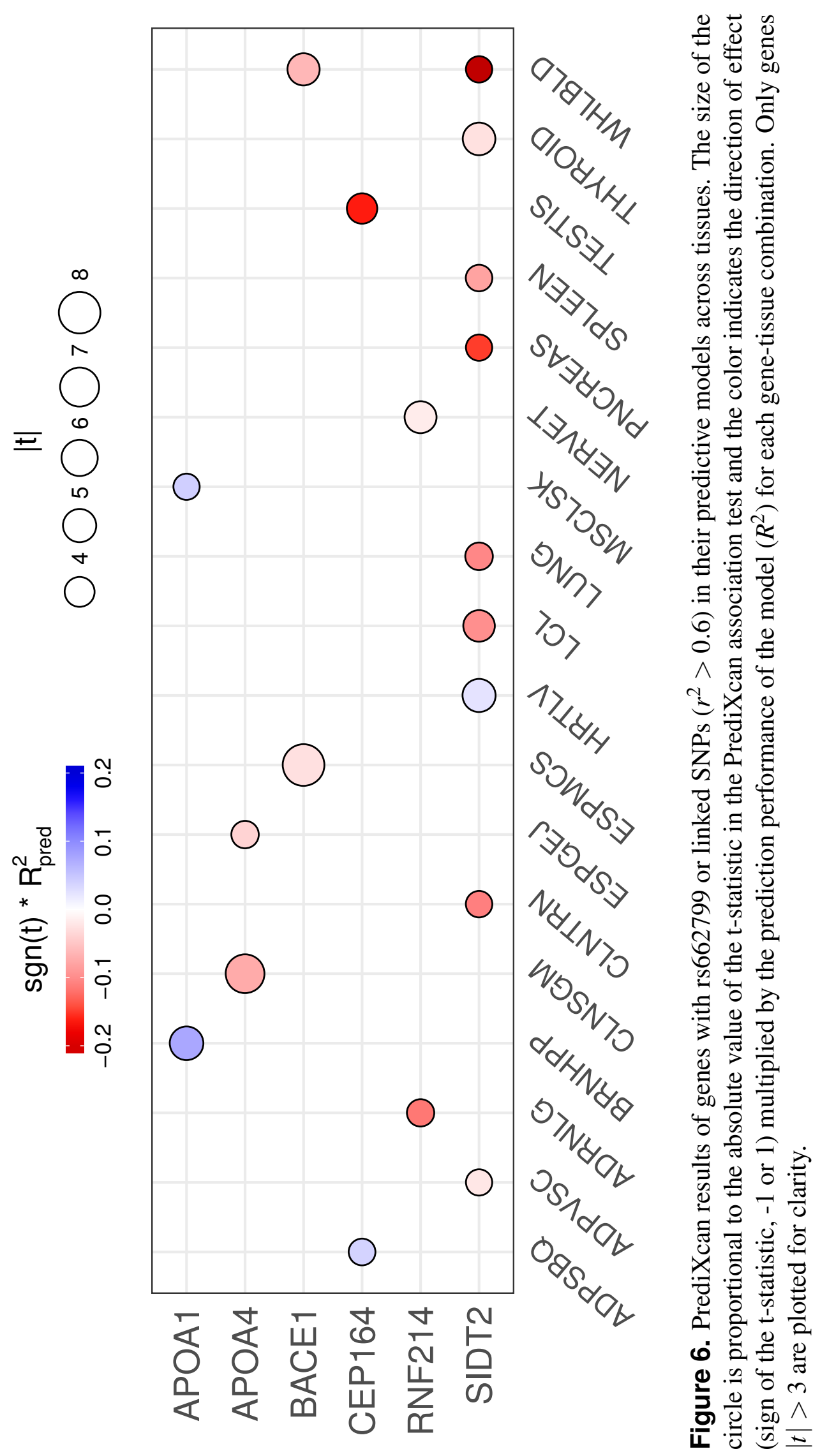


5). There was no overlap in significant genes between Yoruba and GLGC, but there was overlap in significant genes between Cebu and GLGC in FNDC4, SIDT2, APOA4, and BACE1 with the same effect direction for all genes (Willer et al., 2013) (Table 5).

\section{DISCUSSION}

Using genome-wide genotypes and lipid levels obtained in two diverse populations from Ibadan, Nigeria and Cebu, Philippines, we performed multiple genome-wide analyses with the goal of better understanding the underlying genetic architecture of cholesterol traits in both populations.

\section{Top GWAS SNPs have been previously shown to associate with lipid traits}

Within the Yoruba portion of our study, rs34065661 and rs17231520, SNPs close to or within CETP, were significant (Figure 1A). CETP, cholesteryl ester transfer protein, is a well-known lipid gene previously implicated in lipid studies in African populations (Buyske et al., 2012; Elbers et al., 2012). CETP is involved in the transfer of cholesterol from HDL to other lipoproteins, and is a common genetic target for statins and other cholesterol-lowering drugs (Barter et al., 2003). It also has strong association with Alzheimer's disease and other neurodegenerative diseases (Xiao et al., 2012). Additional significant SNPs in Yoruba, rs1065853, rs7412, and rs75627662, are located near or within $A P O E$ (Figure 1B). APOE, apolipoprotein E, another well-known cholesterol gene previously implicated in other lipid studies (Rasmussen-Torvik et al., 2012; Surakka et al., 2014; Mahley, 2016; Spracklen et al., 2017; Zhu et al., 2017). It acts as a lipid transport protein in high association with LDL receptors and is also strongly associated with neurodegenerative diseases (Moriarty et al., 2017).

The most significant SNP within the Cebu GWAS portion of our study is rs662799, at $\mathrm{P}=$ $2.7 \times 10^{-16}$. It has been previously associated with cholesterol traits in Asian populations $(\mathrm{Lu}$ et al., 2016; Spracklen et al., 2017) (Figure 2). APOA5 is a well-documented gene associated with triglyceride levels (Go et al., 2013). Other genes within this linkage group include ZPRI and $B U D 13$, which have both been previously implicated with triglyceride levels in East Asians as well, possibly due to its higher minor allele frequency in those populations (Kim et al., 2011; Lin et al., 2016) (Figure 3).

\section{The mechanism underlying the association of rs662799 with TRIG levels may include long distance regulation of BACE1 and SIDT2}

In our PrediXcan analysis, BACE1 reached significance (FDR $\left.=3.0 \times 10^{-10}\right)$ in both the Cebu and GLGC replication cohorts, but it was not significant in Yoruba (Figure 4). Currently, in humans, $B A C E 1$ is known to increase risk of Alzheimer's disease with increased expression (Cole and Vassar, 2007). While not recognized as significant in the GLGC SNP meta-analysis (Willer et al., 2013), our application of PrediXcan to the GLGC GWAS results verified that the BACE1 association with TRIG is significant $\left(\mathrm{P}=7.3 \times 10^{-19}\right)$ (Table 5 ).

This gene has been studied in terms of Alzheimer's disease and weight gain in mice. In our results, we found increased predicted gene expression for BACE1 to be associated with lower TRIG levels (Figure 5). For BACE1 knockout mice, there was no significant difference in triglyceride levels versus wild-type mice, but they did have lower average body weight (Meakin et al., 2012). Additionally, in mice, higher triglyceride levels were found to reduce BACEl expression in a study 
concerning Alzheimer's treatment (Baek et al., 2016). This latter result is consistent with our finding that increased BACE1 expression is associated with lower triglyceride levels (Figure 5).

The SNP rs662799 is 571 bases upstream of the gene with which it is typically associated, APOA5 (Figure 2). APOA5 was well-predicted in only one tissue, SNTTRM, and the prediction was not driven by SNPs linked to rs662799. Thus, APOA5 may not affect TRIG levels through the mechanism of variation in gene expression regulation. Even though rs662799 is located $493 \mathrm{~kb}$ downstream of $B A C E 1$, it has the largest effect size, i.e. it is the driver SNP, in the predictive model for $B A C E 1$ in ESPMCS. SNPs closer to BACE1 are not linked to rs662799 (Figure 2). The similar effects and significance of $B A C E 1$ in mouse studies, the Cebu cohort analysis, and GLGC PrediXcan results indicate the increased expression of $B A C E 1$ is associated with decreased TRIG levels and that variation in the regulation of $B A C E 1$ may contribute to differences in TRIG levels.

Another significant gene in our gene-based association study of TRIG in Cebu is SIDT2, which is $386 \mathrm{~kb}$ downstream of rs662799. Here, the effects of many SNPs, including some linked to rs662799, combine in the prediction model for SIDT2 gene expression, with no dominant driver SNP, as demonstrated by the lack of discernible clusters in the plot of TRIG levels versus predicted expression (Figure 5). Additionally, SIDT2 exhibits more consistent effect sizes over more tissues than BACE1 (Figure 6), in which predicted expression is associated with higher TRIG levels (Figure 5).

SIDT2, along with others nearby on the same chromosome, has been previously implicated in East Asian GWAS (Gombojav et al., 2015). In our results, we found increased predicted gene expression for SIDT2 to be associated with lower TRIG levels in most models. SIDT2 has been associated with glucose and lipid metabolism in mice, as SIDT2 knockout mice have significantly higher serum levels of TRIG than wild-type mice (Gao et al., 2016). Since increased gene expression is associated with lower TRIG levels in our cohort for a majority of models, our models concur with the association present within mice. Significance of SIDT2 for TRIG in LCL was also replicated in GLGC at $\mathrm{P}=1.1 \times 10^{-102}$ (Table 5). The similar effects and significance of SIDT2 in knockout mice studies, the Cebu cohort analysis, and GLGC PrediXcan results indicate the increased expression of SIDT2 as associated with decreased TRIG levels. Therefore, variation in the regulation of SIDT2 may contribute to differences in TRIG levels.

In an attempt to disentangle the multiple genes associated with TRIG at the 11q23.3 locus, we performed backwards elimination modeling. This analysis showed that $B A C E 1$ has the strongest effect at the locus, with SIDT2, APOA1, and CEP164 contributing smaller effects.

\section{rs662799 has a greater impact in East Asian populations}

The significant SNPs in the GWAS portion of our study have been previously associated with lipid traits, but these prior studies did not conduct a robust gene-based association modeling (Hall et al., 2006; Buyske et al., 2012; Rasmussen-Torvik et al., 2012). In our PrediXcan analysis, we implicated a new gene (PAX6) in Yoruba and additional genes at the chromosome 11 locus in Cebu, including genes with predictive SNPs located hundreds of thousands of base pairs away from their transcription start sites.

rs662799 in particular is a significant SNP in cholesterol GWAS of East Asians (Teslovich et al., 2010; Wu et al., 2013; Lin et al., 2016; Lu et al., 2016; Spracklen et al., 2017), with its minor allele frequency as high as 0.37 in the 1000 Genomes Japanese (JPT) population, and it is also the top SNP, with a minor allele frequency of 0.245 , in our own TRIG GWAS analysis for Cebu (Table 3). rs662799 has a low minor frequency in European and African populations, indicating that even 
if effects are similar, it has a lower allelic impact in European and African ancestry populations (Figure 3). In Asian populations, therefore, rs662799 has a more significant genetic impact (Brown et al. 2016) due to its higher MAF, causing the difference in phenotypic effects. This demonstrates how prediction models may vary in utility across populations.

\section{CONCLUSIONS}

In this study, we use a transcriptome-informed approach to implicate new genes in lipid traits. Limitations arose from the small sample sizes in desired populations and the lack of population-specific transcriptome prediction models. Other lipid trait GWAS, such as the GLGC, included over 180,000 individuals of European ancestry (Willer et al. 2013), while each population in this study had less than 2,000 individuals. Current GTEx models are based on an 85\% European-American and 15\% African-American population, which cannot be fully extrapolated to diverse populations. While Yoruba in Ibadan, Nigeria is a HapMap population, and specific reference panels exist for African populations, there is a lack of publicly available data for southeast Asian and Pacific Islander populations, which is an issue due to the rarer variants in more isolated island populations (Loh et al., 2016). For example, the reference panel used for imputation, 1000 Genomes Phase 3, contains only Vietnamese, Chinese, and Japanese genotypes for East Asian populations (Auton et al., 2015). Without data collection and proper models for non-European populations, there is less potential for accurate implementation of precision medicine. To fully characterize the impact of genetic variation between populations, larger studies in non-European populations are needed.

\section{ACKNOWLEDGMENTS}

The datasets used for the analyses described in this manuscript were obtained from $\mathrm{dbGaP}$ at http://www.ncbi.nlm.nih.gov/gap through accession numbers phs000378.v1.p1 and phs000523.v1.p1. Gene expression prediction models were obtained from PredictDB at http: //predictab.hakyimlab.org/. 


\section{REFERENCES}

Adair, L. S., Popkin, B. M., Akin, J. S., Guilkey, D. K., Gultiano, S., Borja, J., Perez, L., Kuzawa, C. W., McDade, T., and Hindin, M. J. (2011). Cohort profile: The cebu longitudinal health and nutrition survey. International Journal of Epidemiology, 40(3):619-625.

Ahlqvist, E., Turrini, F., Lang, S. T., Taneera, J., Zhou, Y., Almgren, P., Hansson, O., Isomaa, B., Tuomi, T., Eriksson, K., Eriksson, J. G., Lyssenko, V., and Groop, L. (2012). A common variant upstream of the PAX6 gene influences islet function in man. Diabetologia, 55(1):94-104.

Ardlie, K. G., Deluca, D. S., Segrè, A. V., Sullivan, T. J., Young, T. R., Gelfand, E. T., Trowbridge, C. A., Maller, J. B., Tukiainen, T., Lek, M., Ward, L. D., Kheradpour, P., Iriarte, B., Meng, Y., Palmer, C. D., Esko, T., Winckler, W., Hirschhorn, J. N., Kellis, M., MacArthur, D. G., Getz, G., Shabalin, A. A., Li, G., Zhou, Y.-H., Nobel, A. B., Rusyn, I., Wright, F. A., Lappalainen, T., Ferreira, P. G., Ongen, H., Rivas, M. A., Battle, A., Mostafavi, S., Monlong, J., Sammeth, M., Mele, M., Reverter, F., Goldmann, J. M., Koller, D., Guigó, R., McCarthy, M. I., Dermitzakis, E. T., Gamazon, E. R., Im, H. K., Konkashbaev, A., Nicolae, D. L., Cox, N. J., Flutre, T., Wen, X., Stephens, M., Pritchard, J. K., Tu, Z., Zhang, B., Huang, T., Long, Q., Lin, L., Yang, J., Zhu, J., Liu, J., Brown, A., Mestichelli, B., Tidwell, D., Lo, E., Salvatore, M., Shad, S., Thomas, J. A., Lonsdale, J. T., Moser, M. T., Gillard, B. M., Karasik, E., Ramsey, K., Choi, C., Foster, B. A., Syron, J., Fleming, J., Magazine, H., Hasz, R., Walters, G. D., Bridge, J. P., Miklos, M., Sullivan, S., Barker, L. K., Traino, H. M., Mosavel, M., Siminoff, L. A., Valley, D. R., Rohrer, D. C., Jewell, S. D., Branton, P. A., Sobin, L. H., Barcus, M., Qi, L., McLean, J., Hariharan, P., Um, K. S., Wu, S., Tabor, D., Shive, C., Smith, A. M., Buia, S. A., Undale, A. H., Robinson, K. L., Roche, N., Valentino, K. M., Britton, A., Burges, R., Bradbury, D., Hambright, K. W., Seleski, J., Korzeniewski, G. E., Erickson, K., Marcus, Y., Tejada, J., Taherian, M., Lu, C., Basile, M., Mash, D. C., Volpi, S., Struewing, J. P., Temple, G. F., Boyer, J., Colantuoni, D., Little, R., Koester, S., Carithers, L. J., Moore, H. M., Guan, P., Compton, C., Sawyer, S. J., Demchok, J. P., Vaught, J. B., Rabiner, C. A., Lockhart, N. C., Ardlie, K. G., Getz, G., Wright, F. A., Kellis, M., Volpi, S., and Dermitzakis, E. T. (2015). The Genotype-Tissue Expression (GTEx) pilot analysis: Multitissue gene regulation in humans. Science, 348(6235):648-660.

Asselbergs, F. W., Guo, Y., Van Iperen, E. P., Sivapalaratnam, S., Tragante, V., Lanktree, M. B., Lange, L. A., Almoguera, B., Appelman, Y. E., Barnard, J., Baumert, J., Beitelshees, A. L., Bhangale, T. R., Chen, Y. D. I., Gaunt, T. R., Gong, Y., Hopewell, J. C., Johnson, T., Kleber, M. E., Langaee, T. Y., Li, M., Li, Y. R., Liu, K., McDonough, C. W., Meijs, M. F., Middelberg, R. P., Musunuru, K., Nelson, C. P., O’Connell, J. R., Padmanabhan, S., Pankow, J. S., Pankratz, N., Rafelt, S., Rajagopalan, R., Romaine, S. P., Schork, N. J., Shaffer, J., Shen, H., Smith, E. N., Tischfield, S. E., Van Der Most, P. J., Van Vliet-Ostaptchouk, J. V., Verweij, N., Volcik, K. A., Zhang, L., Bailey, K. R., Bailey, K. M., Bauer, F., Boer, J. M., Braund, P. S., Burt, A., Burton, P. R., Buxbaum, S. G., Chen, W., Cooper-Dehoff, R. M., Cupples, L. A., Dejong, J. S., Delles, C., Duggan, D., Fornage, M., Furlong, C. E., Glazer, N., Gums, J. G., Hastie, C., Holmes, M. V., Illig, T., Kirkland, S. A., Kivimaki, M., Klein, R., Klein, B. E., Kooperberg, C., Kottke-Marchant, K., Kumari, M., Lacroix, A. Z., Mallela, L., Murugesan, G., Ordovas, J., Ouwehand, W. H., Post, W. S., Saxena, R., Scharnagl, H., Schreiner, P. J., Shah, T., Shields, D. C., Shimbo, D., Srinivasan, S. R., Stolk, R. P., Swerdlow, D. I., Taylor, H. A., Topol, E. J., Toskala, E., Van Pelt, J. L., Van Setten, J., Yusuf, S., Whittaker, J. C., Zwinderman, A. H., Anand, S. S., Balmforth, A. J., Berenson, G. S., Bezzina, C. R., Boehm, B. O., Boerwinkle, E., Casas, J. P., Caulfield, 
M. J., Clarke, R., Connell, J. M., Cruickshanks, K. J., Davidson, K. W., Day, I. N., De Bakker, P. I., Doevendans, P. A., Dominiczak, A. F., Hall, A. S., Hartman, C. A., Hengstenberg, C., Hillege, H. L., Hofker, M. H., Humphries, S. E., Jarvik, G. P., Johnson, J. A., Kaess, B. M., Kathiresan, S., Koenig, W., Lawlor, D. A., März, W., Melander, O., Mitchell, B. D., Montgomery, G. W., Munroe, P. B., Murray, S. S., Newhouse, S. J., Onland-Moret, N. C., Poulter, N., Psaty, B., Redline, S., Rich, S. S., Rotter, J. I., Schunkert, H., Sever, P., Shuldiner, A. R., Silverstein, R. L., Stanton, A., Thorand, B., Trip, M. D., Tsai, M. Y., Van Der Harst, P., Van Der Schoot, E., Van Der Schouw, Y. T., Verschuren, W. M., Watkins, H., Wilde, A. A., Wolffenbuttel, B. H., Whitfield, J. B., Hovingh, G. K., Ballantyne, C. M., Wijmenga, C., Reilly, M. P., Martin, N. G., Wilson, J. G., Rader, D. J., Samani, N. J., Reiner, A. P., Hegele, R. A., Kastelein, J. J., Hingorani, A. D., Talmud, P. J., Hakonarson, H., Elbers, C. C., Keating, B. J., and Drenos, F. (2012). Large-scale gene-centric meta-analysis across 32 studies identifies multiple lipid loci. American Journal of Human Genetics, 91(5):823-838.

Aulchenko, Y. S., Ripke, S., Isaacs, A., and van Duijn, C. M. (2007). GenABEL: An R library for genome-wide association analysis. Bioinformatics, 23(10):1294-1296.

Auton, A., Abecasis, G. R., Altshuler, D. M., Durbin, R. M., Abecasis, G. R., Bentley, D. R., Chakravarti, A., Clark, A. G., Donnelly, P., Eichler, E. E., Flicek, P., Gabriel, S. B., Gibbs, R. A., Green, E. D., Hurles, M. E., Knoppers, B. M., Korbel, J. O., Lander, E. S., Lee, C., Lehrach, H., Mardis, E. R., Marth, G. T., McVean, G. A., Nickerson, D. A., Schmidt, J. P., Sherry, S. T., Wang, J., Wilson, R. K., Gibbs, R. A., Boerwinkle, E., Doddapaneni, H., Han, Y., Korchina, V., Kovar, C., Lee, S., Muzny, D., Reid, J. G., Zhu, Y., Wang, J., Chang, Y., Feng, Q., Fang, X., Guo, X., Jian, M., Jiang, H., Jin, X., Lan, T., Li, G., Li, J., Li, Y., Liu, S., Liu, X., Lu, Y., Ma, X., Tang, M., Wang, B., Wang, G., Wu, H., Wu, R., Xu, X., Yin, Y., Zhang, D., Zhang, W., Zhao, J., Zhao, M., Zheng, X., Lander, E. S., Altshuler, D. M., Gabriel, S. B., Gupta, N., Gharani, N., Toji, L. H., Gerry, N. P., Resch, A. M., Flicek, P., Barker, J., Clarke, L., Gil, L., Hunt, S. E., Kelman, G., Kulesha, E., Leinonen, R., McLaren, W. M., Radhakrishnan, R., Roa, A., Smirnov, D., Smith, R. E., Streeter, I., Thormann, A., Toneva, I., Vaughan, B., Zheng-Bradley, X., Bentley, D. R., Grocock, R., Humphray, S., James, T., Kingsbury, Z., Lehrach, H., Sudbrak, R., Albrecht, M. W., Amstislavskiy, V. S., Borodina, T. A., Lienhard, M., Mertes, F., Sultan, M., Timmermann, B., Yaspo, M.-L., Mardis, E. R., Wilson, R. K., Fulton, L., Fulton, R., Sherry, S. T., Ananiev, V., Belaia, Z., Beloslyudtsev, D., Bouk, N., Chen, C., Church, D., Cohen, R., Cook, C., Garner, J., Hefferon, T., Kimelman, M., Liu, C., Lopez, J., Meric, P., O’Sullivan, C., Ostapchuk, Y., Phan, L., Ponomarov, S., Schneider, V., Shekhtman, E., Sirotkin, K., Slotta, D., Zhang, H., McVean, G. A., Durbin, R. M., Balasubramaniam, S., Burton, J., Danecek, P., Keane, T. M., Kolb-Kokocinski, A., McCarthy, S., Stalker, J., Quail, M., Schmidt, J. P., Davies, C. J., Gollub, J., Webster, T., Wong, B., Zhan, Y., Auton, A., Campbell, C. L., Kong, Y., Marcketta, A., Gibbs, R. A., Yu, F., Antunes, L., Bainbridge, M., Muzny, D., Sabo, A., Huang, Z., Wang, J., Coin, L. J. M., Fang, L., Guo, X., Jin, X., Li, G., Li, Q., Li, Y., Li, Z., Lin, H., Liu, B., Luo, R., Shao, H., Xie, Y., Ye, C., Yu, C., Zhang, F., Zheng, H., Zhu, H., Alkan, C., Dal, E., Kahveci, F., Marth, G. T., Garrison, E. P., Kural, D., Lee, W.-P., Fung Leong, W., Stromberg, M., Ward, A. N., Wu, J., Zhang, M., Daly, M. J., DePristo, M. A., Handsaker, R. E., Altshuler, D. M., Banks, E., Bhatia, G., del Angel, G., Gabriel, S. B., Genovese, G., Gupta, N., Li, H., Kashin, S., Lander, E. S., McCarroll, S. A., Nemesh, J. C., Poplin, R. E., Yoon, S. C., Lihm, J., Makarov, V., Clark, A. G., Gottipati, S., Keinan, A., Rodriguez-Flores, J. L., Korbel, J. O., Rausch, T., Fritz, M. H., Stütz, A. M., Flicek, P., Beal, K., Clarke, L., Datta, A., Herrero, J., McLaren, W. M., Ritchie, G. R. S., Smith, R. E., Zerbino, 
D., Zheng-Bradley, X., Sabeti, P. C., Shlyakhter, I., Schaffner, S. F., Vitti, J., Cooper, D. N., Ball, E. V., Stenson, P. D., Bentley, D. R., Barnes, B., Bauer, M., Keira Cheetham, R., Cox, A., Eberle, M., Humphray, S., Kahn, S., Murray, L., Peden, J., Shaw, R., Kenny, E. E., Batzer, M. A., Konkel, M. K., Walker, J. A., MacArthur, D. G., Lek, M., Sudbrak, R., Amstislavskiy, V. S., Herwig, R., Mardis, E. R., Ding, L., Koboldt, D. C., Larson, D., Ye, K., Gravel, S., Swaroop, A., Chew, E., Lappalainen, T., Erlich, Y., Gymrek, M., Frederick Willems, T., Simpson, J. T., Shriver, M. D., Rosenfeld, J. A., Bustamante, C. D., Montgomery, S. B., De La Vega, F. M., Byrnes, J. K., Carroll, A. W., DeGorter, M. K., Lacroute, P., Maples, B. K., Martin, A. R., Moreno-Estrada, A., Shringarpure, S. S., Zakharia, F., Halperin, E., Baran, Y., Lee, C., Cerveira, E., Hwang, J., Malhotra, A., Plewczynski, D., Radew, K., Romanovitch, M., Zhang, C., Hyland, F. C. L., Craig, D. W., Christoforides, A., Homer, N., Izatt, T., Kurdoglu, A. A., Sinari, S. A., Squire, K., Sherry, S. T., Xiao, C., Sebat, J., Antaki, D., Gujral, M., Noor, A., Ye, K., Burchard, E. G., Hernandez, R. D., Gignoux, C. R., Haussler, D., Katzman, S. J., James Kent, W., Howie, B., Ruiz-Linares, A., Dermitzakis, E. T., Devine, S. E., Abecasis, G. R., Min Kang, H., Kidd, J. M., Blackwell, T., Caron, S., Chen, W., Emery, S., Fritsche, L., Fuchsberger, C., Jun, G., Li, B., Lyons, R., Scheller, C., Sidore, C., Song, S., Sliwerska, E., Taliun, D., Tan, A., Welch, R., Kate Wing, M., Zhan, X., Awadalla, P., Hodgkinson, A., Li, Y., Shi, X., Quitadamo, A., Lunter, G., McVean, G. A., Marchini, J. L., Myers, S., Churchhouse, C., Delaneau, O., Gupta-Hinch, A., Kretzschmar, W., Iqbal, Z., Mathieson, I., Menelaou, A., Rimmer, A., Xifara, D. K., Oleksyk, T. K., Fu, Y., Liu, X., Xiong, M., Jorde, L., Witherspoon, D., Xing, J., Eichler, E. E., Browning, B. L., Browning, S. R., Hormozdiari, F., Sudmant, P. H., Khurana, E., Durbin, R. M., Hurles, M. E., Tyler-Smith, C., Albers, C. A., Ayub, Q., Balasubramaniam, S., Chen, Y., Colonna, V., Danecek, P., Jostins, L., Keane, T. M., McCarthy, S., Walter, K., Xue, Y., Gerstein, M. B., Abyzov, A., Balasubramanian, S., Chen, J., Clarke, D., Fu, Y., Harmanci, A. O., Jin, M., Lee, D., Liu, J., Jasmine Mu, X., Zhang, J., Zhang, Y., Li, Y., Luo, R., Zhu, H., Alkan, C., Dal, E., Kahveci, F., Marth, G. T., Garrison, E. P., Kural, D., Lee, W.-P., Ward, A. N., Wu, J., Zhang, M., McCarroll, S. A., Handsaker, R. E., Altshuler, D. M., Banks, E., del Angel, G., Genovese, G., Hartl, C., Li, H., Kashin, S., Nemesh, J. C., Shakir, K., Yoon, S. C., Lihm, J., Makarov, V., Degenhardt, J., Korbel, J. O., Fritz, M. H., Meiers, S., Raeder, B., Rausch, T., Stütz, A. M., Flicek, P., Paolo Casale, F., Clarke, L., Smith, R. E., Stegle, O., Zheng-Bradley, X., Bentley, D. R., Barnes, B., Keira Cheetham, R., Eberle, M., Humphray, S., Kahn, S., Murray, L., Shaw, R., Lameijer, E.-W., Batzer, M. A., Konkel, M. K., Walker, J. A., Ding, L., Hall, I., Ye, K., Lacroute, P., Lee, C., Cerveira, E., Malhotra, A., Hwang, J., Plewczynski, D., Radew, K., Romanovitch, M., Zhang, C., Craig, D. W., Homer, N., Church, D., Xiao, C., Sebat, J., Antaki, D., Bafna, V., Michaelson, J., Ye, K., Devine, S. E., Gardner, E. J., Abecasis, G. R., Kidd, J. M., Mills, R. E., Dayama, G., Emery, S., Jun, G., Shi, X., Quitadamo, A., Lunter, G., McVean, G. A., Chen, K., Fan, X., Chong, Z., Chen, T., Witherspoon, D., Xing, J., Eichler, E. E., Chaisson, M. J., Hormozdiari, F., Huddleston, J., Malig, M., Nelson, B. J., Sudmant, P. H., Parrish, N. F., Khurana, E., Hurles, M. E., Blackburne, B., Lindsay, S. J., Ning, Z., Walter, K., Zhang, Y., Gerstein, M. B., Abyzov, A., Chen, J., Clarke, D., Lam, H., Jasmine Mu, X., Sisu, C., Zhang, J., Zhang, Y., Gibbs, R. A., Yu, F., Bainbridge, M., Challis, D., Evani, U. S., Kovar, C., Lu, J., Muzny, D., Nagaswamy, U., Reid, J. G., Sabo, A., Yu, J., Guo, X., Li, W., Li, Y., Wu, R., Marth, G. T., Garrison, E. P., Fung Leong, W., Ward, A. N., del Angel, G., DePristo, M. A., Gabriel, S. B., Gupta, N., Hartl, C., Poplin, R. E., Clark, A. G., Rodriguez-Flores, J. L., Flicek, P., Clarke, L., Smith, R. E., Zheng-Bradley, X., MacArthur, D. G., Mardis, E. R., Fulton, R., Koboldt, D. C., Gravel, S., Bustamante, C. D., Craig, D. W., 
Christoforides, A., Homer, N., Izatt, T., Sherry, S. T., Xiao, C., Dermitzakis, E. T., Abecasis, G. R., Min Kang, H., McVean, G. A., Gerstein, M. B., Balasubramanian, S., Habegger, L., Yu, H., Flicek, P., Clarke, L., Cunningham, F., Dunham, I., Zerbino, D., Zheng-Bradley, X., Lage, K., Berg Jespersen, J., Horn, H., Montgomery, S. B., DeGorter, M. K., Khurana, E., Tyler-Smith, C., Chen, Y., Colonna, V., Xue, Y., Gerstein, M. B., Balasubramanian, S., Fu, Y., Kim, D., Auton, A., Marcketta, A., Desalle, R., Narechania, A., Wilson Sayres, M. A., Garrison, E. P., Handsaker, R. E., Kashin, S., McCarroll, S. A., Rodriguez-Flores, J. L., Flicek, P., Clarke, L., Zheng-Bradley, X., Erlich, Y., Gymrek, M., Frederick Willems, T., Bustamante, C. D., Mendez, F. L., David Poznik, G., Underhill, P. A., Lee, C., Cerveira, E., Malhotra, A., Romanovitch, M., Zhang, C., Abecasis, G. R., Coin, L., Shao, H., Mittelman, D., Tyler-Smith, C., Ayub, Q., Banerjee, R., Cerezo, M., Chen, Y., Fitzgerald, T. W., Louzada, S., Massaia, A., McCarthy, S., Ritchie, G. R., Xue, Y., Yang, F., Gibbs, R. A., Kovar, C., Kalra, D., Hale, W., Muzny, D., Reid, J. G., Wang, J., Dan, X., Guo, X., Li, G., Li, Y., Ye, C., Zheng, X., Altshuler, D. M., Flicek, P., Clarke, L., Zheng-Bradley, X., Bentley, D. R., Cox, A., Humphray, S., Kahn, S., Sudbrak, R., Albrecht, M. W., Lienhard, M., Larson, D., Craig, D. W., Izatt, T., Kurdoglu, A. A., Sherry, S. T., Xiao, C., Haussler, D., Abecasis, G. R., McVean, G. A., Durbin, R. M., Balasubramaniam, S., Keane, T. M., McCarthy, S., Stalker, J., Chakravarti, A., Knoppers, B. M., Abecasis, G. R., Barnes, K. C., Beiswanger, C., Burchard, E. G., Bustamante, C. D., Cai, H., Cao, H., Durbin, R. M., Gerry, N. P., Gharani, N., Gibbs, R. A., Gignoux, C. R., Gravel, S., Henn, B., Jones, D., Jorde, L., Kaye, J. S., Keinan, A., Kent, A., Kerasidou, A., Li, Y., Mathias, R., McVean, G. A., Moreno-Estrada, A., Ossorio, P. N., Parker, M., Resch, A. M., Rotimi, C. N., Royal, C. D., Sandoval, K., Su, Y., Sudbrak, R., Tian, Z., Tishkoff, S., Toji, L. H., Tyler-Smith, C., Via, M., Wang, Y., Yang, H., Yang, L., Zhu, J., Bodmer, W., Bedoya, G., Ruiz-Linares, A., Cai, Z., Gao, Y., Chu, J., Peltonen, L., Garcia-Montero, A., Orfao, A., Dutil, J., Martinez-Cruzado, J. C., Oleksyk, T. K., Barnes, K. C., Mathias, R. A., Hennis, A., Watson, H., McKenzie, C., Qadri, F., LaRocque, R., Sabeti, P. C., Zhu, J., Deng, X., Sabeti, P. C., Asogun, D., Folarin, O., Happi, C., Omoniwa, O., Stremlau, M., Tariyal, R., Jallow, M., Sisay Joof, F., Corrah, T., Rockett, K., Kwiatkowski, D., Kooner, J., Tinh Hien, T., Dunstan, S. J., Thuy Hang, N., Fonnie, R., Garry, R., Kanneh, L., Moses, L., Sabeti, P. C., Schieffelin, J., Grant, D. S., Gallo, C., Poletti, G., Saleheen, D., Rasheed, A., Brooks, L. D., Felsenfeld, A. L., McEwen, J. E., Vaydylevich, Y., Green, E. D., Duncanson, A., Dunn, M., Schloss, J. A., Wang, J., Yang, H., Auton, A., Brooks, L. D., Durbin, R. M., Garrison, E. P., Min Kang, H., Korbel, J. O., Marchini, J. L., McCarthy, S., McVean, G. A., and Abecasis, G. R. (2015). A global reference for human genetic variation. Nature, 526(7571):68-74.

Ayellet, V. S., Groop, L., Mootha, V. K., Daly, M. J., and Altshuler, D. (2010). Common inherited variation in mitochondrial genes is not enriched for associations with type 2 diabetes or related glycemic traits. PLoS Genetics, 6(8).

Baek, S. H., Choi, B. Y., Cho, Y., Kim, H., Jung, G. Y., Park, H. J., Han, J., Bahn, G., and Jo, D.-G. (2016). The Drug Triglyceride Reducing BACE1 Expression Level and Preventing Cognitive Impairment in Alzheimer's Disease Mice. Alzheimer's \& Dementia, 12(7):P434-P435.

Barbeira, A., Dickinson, S. P., Torres, J. M., Torstenson, E. S., Zheng, J., Wheeler, H. E., Shah, K. P., Edwards, T., Consortium, G., Nicolae, D., Cox, N. J., and Im, H. K. (2017). Integrating tissue specific mechanisms into GWAS summary results. bioRxiv, page 045260.

Barter, P. J., Brewer, H. B., Chapman, M. J., Hennekens, C. H., Rader, D. J., and Tall, A. R. (2003). Cholesteryl ester transfer protein: A novel target for raising HDL and inhibiting atherosclerosis. Arteriosclerosis, Thrombosis, and Vascular Biology, 23(2):160-167. 
Brown, B. C., Ye, C. J., Price, A. L., and Zaitlen, N. (2016). Transethnic Genetic-Correlation Estimates from Summary Statistics. American Journal of Human Genetics, 99(1):76-88.

Bustamante, C. D., De La Vega, F. M., and Burchard, E. G. (2011). Genomics for the world. Nature, 475(7355):163-165.

Buyske, S., Wu, Y., Carty, C. L., Cheng, I., Assimes, T. L., Dumitrescu, L., Hindorff, L. A., Mitchell, S., Ambite, J. L., Boerwinkle, E., Buzkova, P., Carlson, C. S., Cochran, B., Duggan, D., Eaton, C. B., Fesinmeyer, M. D., Franceschini, N., Haessler, J., Jenny, N., Kang, H. M., Kooperberg, C., Lin, Y., Marchand, L., Matise, T. C., Robinson, J. G., Rodriguez, C., Schumacher, F. R., Voight, B. F., Young, A., Manolio, T. A., Mohlke, K. L., Haiman, C. A., Peters, U., Crawford, D. C., and North, K. E. (2012). Evaluation of the metabochip genotyping array in african americans and implications for fine mapping of gwas-identified loci: The PAGE study. PLoS ONE, 7(4):32118-32119.

Cole, S. L. and Vassar, R. (2007). The Alzheimer's disease Beta-secretase enzyme, BACE1. Molecular Neurodegeneration, 2(1):22.

Coram, M. A., Candille, S. I., Duan, Q., Chan, K. H. K., Li, Y., Kooperberg, C., Reiner, A. P., and Tang, H. (2015). Leveraging multi-ethnic evidence for mapping complex traits in minority populations: An empirical Bayes approach. American Journal of Human Genetics, 96(5):740-752.

Das, S., Forer, L., Schönherr, S., Sidore, C., Locke, A., Kwong, A., Vrieze, S., Chew, E., Levy, S., McGue, M., Schlessinger, D., Stambolian, D., Loh, P., Iacono, W., Swaroop, A., Scott, L., Cucca, F., Kronenberg, F., Boehnke, M., Abecasis, G., and Fuchsberger, C. (2016). Next-generation genotype imputation service and methods. Nature Genetics, 48(10):1284-1287.

Delaneau, O., Marchini, J., and Zagury, J.-F. (2012). A linear complexity phasing method for thousands of genomes. Nature Methods, 9(2):179-181.

Durbin, R. (2014). Efficient haplotype matching and storage using the positional Burrows-Wheeler transform (PBWT). Bioinformatics, 30(9):1266-1272.

Elbers, C. C., Guo, Y., Tragante, V., van Iperen, E. P. A., Lanktree, M. B., Castillo, B. A., Chen, F., Yanek, L. R., Wojczynski, M. K., Li, Y. R., Ferwerda, B., Ballantyne, C. M., Buxbaum, S. G., Chen, Y. D. I., Chen, W. M., Cupples, L. A., Cushman, M., Duan, Y., Duggan, D., Evans, M. K., Fernandes, J. K., Fornage, M., Garcia, M., Garvey, W. T., Glazer, N., Gomez, F., Harris, T. B., Halder, I., Howard, V. J., Keller, M. F., Kamboh, M. I., Kooperberg, C., Kritchevsky, S. B., LaCroix, A., Liu, K., Liu, Y., Musunuru, K., Newman, A. B., Onland-Moret, N. C., Ordovas, J., Peter, I., Post, W., Redline, S., Reis, S. E., Saxena, R., Schreiner, P. J., Volcik, K. A., Wang, X., Yusuf, S., Zonderland, A. B., Anand, S. S., Becker, D. M., Psaty, B., Rader, D. J., Reiner, A. P., Rich, S. S., Rotter, J. I., Sale, M. M., Tsai, M. Y., Borecki, I. B., Hegele, R. A., Kathiresan, S., Nalls, M. A., Taylor, H. A., Hakonarson, H., Sivapalaratnam, S., Asselbergs, F. W., Drenos, F., Wilson, J. G., and Keating, B. J. (2012). Gene-Centric Meta-Analysis of Lipid Traits in African, East Asian and Hispanic Populations. PLoS ONE, 7(12):1-14.

Ellulu, M., Abed, Y., Rahmat, A., Ranneh, Y., and Ali, F. (2014). Epidemiology of obesity in developing countries: challenges and prevention. Global Epidemic Obesity, 2(1):2.

Gamazon, E. R., Wheeler, H. E., Shah, K. P., Mozaffari, S. V., Aquino-Michaels, K., Carroll, R. J., Eyler, A. E., Denny, J. C., Nicolae, D. L., Cox, N. J., and Im, H. K. (2015). A gene-based association method for mapping traits using reference transcriptome data. Nature Genetics, 47(9):1091-1098.

Gao, J., Zhang, Y., Yu, C., Tan, F., and Wang, L. (2016). Spontaneous nonalcoholic fatty liver disease 
and ER stress in Sidt2 deficiency mice. Biochemical and Biophysical Research Communications, 476(4):326-332.

Go, A. S., Mozaffarian, D., Roger, V. L., Benjamin, E. J., Berry, J. D., Borden, W. B., Bravata, D. M., Dai, S., Ford, E. S., Fox, C. S., Franco, S., Fullerton, H. J., Gillespie, C., Hailpern, S. M., Heit, J. A., Howard, V. J., Huffman, M. D., Kissela, B. M., Kittner, S. J., Lackland, D. T., Lichtman, J. H., Lisabeth, L. D., Magid, D., Marcus, G. M., Marelli, A., Matchar, D. B., McGuire, D. K., Mohler, E. R., Moy, C. S., Mussolino, M. E., Nichol, G., Paynter, N. P., Schreiner, P. J., Sorlie, P. D., Stein, J., Turan, T. N., Virani, S. S., Wong, N. D., Woo, D., and Turner, M. B. (2013). Heart disease and stroke statistics - 2013 update: A Report from the American Heart Association. Circulation, 127(1).

Gombojav, B., Lee, S. J., Kho, M., Song, Y.-M., Lee, K., and Sung, J. (2015). Multiple Susceptibility Loci at Chromosome 11q23.3 are Associated with Plasma Triglyceride in East Asians. Journal of Lipid Research, 57:jlr.P063461.

Gusev, A., Ko, A., Shi, H., Bhatia, G., Chung, W., Penninx, B. W. J. H., Jansen, R., de Geus, E. J. C., Boomsma, D. I., Wright, F. A., Sullivan, P. F., Nikkola, E., Alvarez, M., Civelek, M., Lusis, A. J., Lehtimaki, T., Raitoharju, E., Kahonen, M., Seppala, I., Raitakari, O. T., Kuusisto, J., Laakso, M., Price, A. L., Pajukanta, P., and Pasaniuc, B. (2016). Integrative approaches for large-scale transcriptome-wide association studies. Nature Genetics, 48(3):245-252.

Hall, K., Murrell, J., Ogunniyi, A., Deeg, M., Baiyewu, O., Gao, S., Gureje, O., Dickens, J., Evans, R., Smith-Gamble, V., Unverzagt, F. W., Shen, J., and Hendrie, H. (2006). Cholesterol, APOE genotype, and Alzheimer disease: An epidemiologic study of Nigerian Yoruba. Neurology, 66(2):223-227.

Kim, Y. J., Go, M. J., Hu, C., Hong, C. B., Kim, Y. K., Lee, J. Y., Hwang, J.-y., Oh, J. H., Kim, D.-J., Kim, N. H., Kim, S., Hong, E. J., Kim, J.-H., Min, H., Kim, Y., Zhang, R., Jia, W., Okada, Y., Takahashi, A., Kubo, M., Tanaka, T., Kamatani, N., Matsuda, K., Park, T., Oh, B., Kimm, K., Kang, D., Shin, C., Cho, N. H., Kim, H.-1., Han, B.-G., Lee, J.-Y., and Cho, Y. S. (2011). Large-scale genome-wide association studies in east Asians identify new genetic loci influencing metabolic traits. Nature Genetics, 43(10):990-995.

Lee, S. H., Yang, J., Goddard, M. E., Visscher, P. M., and Wray, N. R. (2012). Estimation of pleiotropy between complex diseases using single-nucleotide polymorphism-derived genomic relationships and restricted maximum likelihood. Bioinformatics, 28(19):2540-2542.

Lin, E., Kuo, P.-h., Liu, Y.-1., Yang, A. C., Kao, C.-f., and Tsai, S.-j. (2016). Association and interaction of APOA5, BUD13, CETP, LIPA and health-related behavior with metabolic syndrome in a Taiwanese population. Nature Publishing Group, (October):1-9.

Loh, P.-R., Danecek, P., Palamara, P. F., Fuchsberger, C., Reshef, Y. A., Finucane, H. K., Schoenherr, S., Forer, L., McCarthy, S., Abecasis, G. R., Durbin, R., and Price, A. L. (2016). Reference-based phasing using the Haplotype Reference Consortium panel. bioRxiv, 48(11):052308.

Lu, X., Huang, J., Mo, Z., He, J., Wang, L., Yang, X., Tan, A., Chen, S., Chen, J., Charles Gu, C., Chen, J., Li, Y., Zhao, L., Li, H., Hao, Y., Li, J., Hixson, J. E., Li, Y., Cheng, M., Liu, X., Cao, J., Liu, F., Huang, C., Shen, C., Shen, J., Yu, L., Xu, L., Mu, J., Wu, X., Ji, X., Guo, D., Zhou, Z., Yang, Z., Wang, R., Yang, J., Yan, W., Peng, X., and Gu, D. (2016). Genetic Susceptibility to Lipid Levels and Lipid Change over Time and Risk of Incident Hyperlipidemia in Chinese Populations. Circulation: Cardiovascular Genetics, 9(1):37-44.

Mahley, R. W. (2016). Apolipoprotein E: from cardiovascular disease to neurodegenerative disorders. Journal of Molecular Medicine, 94(7):739-746. 
Mailman, M. D., Feolo, M., Jin, Y., Kimura, M., Tryka, K., Bagoutdinov, R., Hao, L., Kiang, A., Paschall, J., Phan, L., Popova, N., Pretel, S., Ziyabari, L., Lee, M., Shao, Y., Wang, Z. Y., Sirotkin, K., Ward, M., Kholodov, M., Zbicz, K., Beck, J., Kimelman, M., Shevelev, S., Preuss, D., Yaschenko, E., Graeff, A., Ostell, J., and Sherry, S. T. (2007). The NCBI dbGaP database of genotypes and phenotypes. Nature Genetics, 39(10):1181-1186.

Marcus, J. H. and Novembre, J. (2016). Visualizing the Geography of Genetic Variants. bioRxiv, (October):068536.

McCarthy, S., Das, S., Kretzschmar, W., Delaneau, O., Wood, A. R., Teumer, A., Kang, H. M., Fuchsberger, C., Danecek, P., Sharp, K., Luo, Y., Sidore, C., Kwong, A., Timpson, N., Koskinen, S., Vrieze, S., Scott, L. J., Zhang, H., Mahajan, A., Veldink, J., Peters, U., Pato, C., van Duijn, C. M., Gillies, C. E., Gandin, I., Mezzavilla, M., Gilly, A., Cocca, M., Traglia, M., Angius, A., Barrett, J. C., Boomsma, D., Branham, K., Breen, G., Brummett, C. M., Busonero, F., Campbell, H., Chan, A., Chen, S., Chew, E., Collins, F. S., Corbin, L. J., Smith, G. D., Dedoussis, G., Dorr, M., Farmaki, A.-E., Ferrucci, L., Forer, L., Fraser, R. M., Gabriel, S., Levy, S., Groop, L., Harrison, T., Hattersley, A., Holmen, O. L., Hveem, K., Kretzler, M., Lee, J. C., McGue, M., Meitinger, T., Melzer, D., Min, J. L., Mohlke, K. L., Vincent, J. B., Nauck, M., Nickerson, D., Palotie, A., Pato, M., Pirastu, N., McInnis, M., Richards, J. B., Sala, C., Salomaa, V., Schlessinger, D., Schoenherr, S., Slagboom, P. E., Small, K., Spector, T., Stambolian, D., Tuke, M., Tuomilehto, J., Van den Berg, L. H., Van Rheenen, W., Volker, U., Wijmenga, C., Toniolo, D., Zeggini, E., Gasparini, P., Sampson, M. G., Wilson, J. F., Frayling, T., de Bakker, P. I. W., Swertz, M. A., McCarroll, S., Kooperberg, C., Dekker, A., Altshuler, D., Willer, C., Iacono, W., Ripatti, S., Soranzo, N., Walter, K., Swaroop, A., Cucca, F., Anderson, C. A., Myers, R. M., Boehnke, M., McCarthy, M. I., Durbin, R., and Haplotype Reference Consortium (2016). A reference panel of 64,976 haplotypes for genotype imputation. Nature Genetics, 48(10).

Meakin, P. J., Harper, A. J., Hamilton, D. L., Gallagher, J., McNeilly, A. D., Burgess, L. A., Vaanholt, L. M., Bannon, K. A., Latcham, J., Hussain, I., Speakman, J. R., Howlett, D. R., and Ashford, M. L. J. (2012). Reduction in BACE1 decreases body weight, protects against diet-induced obesity and enhances insulin sensitivity in mice. The Biochemical journal, 441(1):285-96.

Middelberg, R. P. S., Ferreira, M. A. R., Henders, A. K., Heath, A. C., Madden, P. A. F., Montgomery, G. W., Martin, N. G., and Whitfield, J. B. (2011). Genetic variants in LPL, OASL and TOMM40/APOE-C1-C2-C4 genes are associated with multiple cardiovascular-related traits. BMC medical genetics, 12:123.

Moriarty, P. M., Varvel, S. A., Gordts, P. L. S. M., McConnell, J. P., and Tsimikas, S. (2017). Lipoprotein(a) Mass Levels Increase Significantly According to APOE Genotype: An Analysis of 431,239 Patients. Arteriosclerosis, Thrombosis, and Vascular Biology, 37(3):580-588.

Ogunniyi, A., Gureje, O., Baiyewu, O., Unverzagt, F., Hall, K. S., Oluwole, S., Osuntokun, B. O., and Hendrie, H. C. (1997). Profile of dementia in a Nigerian community-types, pattern of impairment, and severity rating. Journal of the National Medical Association, 89(6):392-6.

Patterson, N., Price, A. L., and Reich, D. (2006). Population structure and eigenanalysis. PLoS Genetics, 2(12):2074-2093.

Pruim, R. J., Welch, R. P., Sanna, S., Teslovich, T. M., Chines, P. S., Gliedt, T. P., Boehnke, M., Abecasis, G. R., Willer, C. J., and Frishman, D. (2011). LocusZoom: Regional visualization of genome-wide association scan results. Bioinformatics, 27(13):2336-2337.

Purcell, S., Neale, B., Todd-Brown, K., Thomas, L., Ferreira, M. A. R., Bender, D., Maller, J., Sklar, P., de Bakker, P. I. W., Daly, M. J., and Sham, P. C. (2007). PLINK: A tool set for 
whole-genome association and population-based linkage analyses. American Journal of Human Genetics, 81(3):559-575.

Rasmussen-Torvik, L. J., Pacheco, J. A., Wilke, R. A., Thompson, W. K., Ritchie, M. D., Kho, A. N., Muthalagu, A., Hayes, M. G., Armstrong, L. L., Scheftner, D. A., Wilkins, J. T., Zuvich, R. L., Crosslin, D., Roden, D. M., Denny, J. C., Jarvik, G. P., Carlson, C. S., Kullo, I. J., Bielinski, S. J., Mccarty, C. A., Li, R., Manolio, T. A., Crawford, D. C., and Chisholm, R. L. (2012). High Density GWAS for LDL Cholesterol in African Americans Using Electronic Medical Records Reveals a Strong Protective Variant in APOE. Clinical and Translational Science, 5(5):394-399. Sabatti, C., Service, S. K., Hartikainen, A.-L., Pouta, A., Ripatti, S., Brodsky, J., Jones, C. G., Zaitlen, N. A., Varilo, T., Kaakinen, M., Sovio, U., Ruokonen, A., Laitinen, J., Jakkula, E., Coin, L., Hoggart, C., Collins, A., Turunen, H., Gabriel, S., Elliot, P., McCarthy, M. I., Daly, M. J., Jarvelin, M.-R., Freimer, N. B., and Peltonen, L. (2009). Genome-wide association analysis of metabolic traits in a birth cohort from a founder population. Nature Genetics, 41(1):35-46.

Spracklen, C. N., Chen, P., Kim, Y. J., Wang, X., Cai, H., Li, S., Long, J., Wu, Y., Wang, Y. X., Takeuchi, F., Wu, J. Y., Jung, K. J., Hu, C., Akiyama, K., Zhang, Y., Moon, S., Johnson, T. A., Li, H., Dorajoo, R., He, M., Cannon, M. E., Roman, T. S., Salfati, E., Lin, K. H., Guo, X., Sheu, W. H., Absher, D., Adair, L. S., Assimes, T. L., Aung, T., Cai, Q., Chang, L. C., Chen, C. H., Chien, L. H., Chuang, L. M., Chuang, S. C., Du, S., Fan, Q., Fann, C. S., Feranil, A. B., Friedlander, Y., Gordon-Larsen, P., Gu, D., Gui, L., Guo, Z., Heng, C. K., Hixson, J., Hou, X., Hsiung, C. A., Hu, Y., Hwang, M. Y., Hwu, C. M., Isono, M., Jimmy Juang, J. M., Khor, C. C., Kim, Y. K., Koh, W. P., Kubo, M., Lee, I. T., Lee, S. J., Lee, W. J., Liang, K. W., Lim, B., Lim, S. H., Liu, J., Nabika, T., Pan, W. H., Peng, H., Quertermous, T., Sabanayagam, C., Sandow, K., Shi, J., Sun, L., Tan, P. C., Tan, S. P., Taylor, K. D., Teo, Y. Y., Toh, S. A., Tsunoda, T., van Dam, R. M., Wang, A., Wang, F., Wang, J., Wei, W. B., Xiang, Y. B., Yao, J., Yuan, J. M., Zhang, R., Zhao, W., Ida Chen, Y. D., Rich, S. S., Rotter, J. I., Wang, T. D., Wu, T., Lin, X., Han, B. G., Tanaka, T., Cho, Y. S., Katsuya, T., Jia, W., Jee, S. H., Chen, Y. T., Kato, N., Jonas, J. B., Cheng, C. Y., Shu, X. O., He, J., Zheng, W., Wong, T. Y., Huang, W., Kim, B. J., Tai, E. S., Mohlke, K. L., and Sim, X. (2017). Association analyses of East Asian individuals and trans-ancestry analyses with European individuals reveal new loci associated with cholesterol and triglyceride levels. Human Molecular Genetics, 26(9):1770-1784.

Surakka, I., Horikoshi, M., Mägi, R., and Sarin, A.-p. (2014). The impact of low-frequency and rare variants on lipid levels. Nature Genetics, 47(6):589-597.

Teslovich, T. M., Musunuru, K., Smith, A. V., Edmondson, A. C., Stylianou, I. M., Koseki, M., Pirruccello, J. P., Ripatti, S., Chasman, D. I., Willer, C. J., Johansen, C. T., Fouchier, S. W., Isaacs, A., Peloso, G. M., Barbalic, M., Ricketts, S. L., Bis, J. C., Aulchenko, Y. S., Thorleifsson, G., Feitosa, M. F., Chambers, J., Orho-Melander, M., Melander, O., Johnson, T., Li, X., Guo, X., Li, M., Shin Cho, Y., Jin Go, M., Jin Kim, Y., Lee, J.-Y., Park, T., Kim, K., Sim, X., Twee-Hee Ong, R., Croteau-Chonka, D. C., Lange, L. A., Smith, J. D., Song, K., Hua Zhao, J., Yuan, X., Luan, J., Lamina, C., Ziegler, A., Zhang, W., Zee, R. Y. L., Wright, A. F., Witteman, J. C. M., Wilson, J. F., Willemsen, G., Wichmann, H.-E., Whitfield, J. B., Waterworth, D. M., Wareham, N. J., Waeber, G., Vollenweider, P., Voight, B. F., Vitart, V., Uitterlinden, A. G., Uda, M., Tuomilehto, J., Thompson, J. R., Tanaka, T., Surakka, I., Stringham, H. M., Spector, T. D., Soranzo, N., Smit, J. H., Sinisalo, J., Silander, K., Sijbrands, E. J. G., Scuteri, A., Scott, J., Schlessinger, D., Sanna, S., Salomaa, V., Saharinen, J., Sabatti, C., Ruokonen, A., Rudan, I., Rose, L. M., Roberts, R., Rieder, M., Psaty, B. M., Pramstaller, P. P., Pichler, I., Perola, M., Penninx, B. W. J. H., Pedersen, 
N. L., Pattaro, C., Parker, A. N., Pare, G., Oostra, B. A., O'Donnell, C. J., Nieminen, M. S., Nickerson, D. A., Montgomery, G. W., Meitinger, T., McPherson, R., McCarthy, M. I., McArdle, W., Masson, D., Martin, N. G., Marroni, F., Mangino, M., Magnusson, P. K. E., Lucas, G., Luben, R., Loos, R. J. F., Lokki, M.-L., Lettre, G., Langenberg, C., Launer, L. J., Lakatta, E. G., Laaksonen, R., Kyvik, K. O., Kronenberg, F., König, I. R., Khaw, K.-T., Kaprio, J., Kaplan, L. M., Johansson, A., Jarvelin, M.-R., Janssens, A. C. J. W., Ingelsson, E., Igl, W., Kees Hovingh, G., Hottenga, J.-J., Hofman, A., Hicks, A. A., Hengstenberg, C., Heid, I. M., Hayward, C., Havulinna, A. S., Hastie, N. D., Harris, T. B., Haritunians, T., Hall, A. S., Gyllensten, U., Guiducci, C., Groop, L. C., Gonzalez, E., Gieger, C., Freimer, N. B., Ferrucci, L., Erdmann, J., Elliott, P., Ejebe, K. G., Döring, A., Dominiczak, A. F., Demissie, S., Deloukas, P., de Geus, E. J. C., de Faire, U., Crawford, G., Collins, F. S., Chen, Y.-d. I., Caulfield, M. J., Campbell, H., Burtt, N. P., Bonnycastle, L. L., Boomsma, D. I., Boekholdt, S. M., Bergman, R. N., Barroso, I., Bandinelli, S., Ballantyne, C. M., Assimes, T. L., Quertermous, T., Altshuler, D., Seielstad, M., Wong, T. Y., Tai, E.-S., Feranil, A. B., Kuzawa, C. W., Adair, L. S., Taylor, H. A., Borecki, I. B., Gabriel, S. B., Wilson, J. G., Holm, H., Thorsteinsdottir, U., Gudnason, V., Krauss, R. M., Mohlke, K. L., Ordovas, J. M., Munroe, P. B., Kooner, J. S., Tall, A. R., Hegele, R. A., Kastelein, J. J. P., Schadt, E. E., Rotter, J. I., Boerwinkle, E., Strachan, D. P., Mooser, V., Stefansson, K., Reilly, M. P., Samani, N. J., Schunkert, H., Cupples, L. A., Sandhu, M. S., Ridker, P. M., Rader, D. J., van Duijn, C. M., Peltonen, L., Abecasis, G. R., Boehnke, M., and Kathiresan, S. (2010). Biological, clinical and population relevance of 95 loci for blood lipids. Nature, 466(7307):707-13.

Turner, S., Armstrong, L. L., Bradford, Y., Carlson, C. S., Crawford, D. C., Crenshaw, A. T., de Andrade, M., Doheny, K. F., Haines, J. L., Hayes, G., Jarvik, G., Jiang, L., Kullo, I. J., Li, R., Ling, H., Manolio, T. A., Matsumoto, M., McCarty, C. A., McDavid, A. N., Mirel, D. B., Paschall, J. E., Pugh, E. W., Rasmussen, L. V., Wilke, R. A., Zuvich, R. L., and Ritchie, M. D. (2001). Quality Control Procedures for Genome-Wide Association Studies. In Current Protocols in Human Genetics. John Wiley \& Sons, Inc.

Wheeler, H. E., Shah, K. P., Brenner, J., Garcia, T., Aquino-Michaels, K., Cox, N. J., Nicolae, D. L., and Im, H. K. (2016). Survey of the Heritability and Sparse Architecture of Gene Expression Traits across Human Tissues. PLoS Genetics, 12(11):1-23.

Wickham, H., Winston, C., and RStudio (2016). ggplot2: Create Elegant Data Visualisations Using the Grammar of Graphics.

Willer, C. J., Schmidt, E. M., Sengupta, S., Peloso, G. M., Gustafsson, S., Kanoni, S., Ganna, A., Chen, J., Buchkovich, M. L., Mora, S., Beckmann, J. S., Bragg-Gresham, J. L., Chang, H.-Y., Demirkan, A., Den Hertog, H. M., Do, R., Donnelly, L. A., Ehret, G. B., Esko, T., Feitosa, M. F., Ferreira, T., Fischer, K., Fontanillas, P., Fraser, R. M., Freitag, D. F., Gurdasani, D., Heikkilä, K., Hyppönen, E., Isaacs, A., Jackson, A. U., Johansson, A., Johnson, T., Kaakinen, M., Kettunen, J., Kleber, M. E., Li, X., Luan, J., Lyytikäinen, L.-P., Magnusson, P. K. E., Mangino, M., Mihailov, E., Montasser, M. E., Müller-Nurasyid, M., Nolte, I. M., O'Connell, J. R., Palmer, C. D. C. N. A., Perola, M., Petersen, A.-K., Sanna, S., Saxena, R., Service, S. K., Shah, S., Shungin, D., Sidore, C., Song, C., Strawbridge, R. J., Surakka, I., Tanaka, T., Teslovich, T. M., Thorleifsson, G., Van den Herik, E. G., Voight, B. F., Volcik, K. A., Waite, L. L., Wong, A., Wu, Y., Zhang, W., Absher, D., Asiki, G., Barroso, I., Been, L. F., Bolton, J. L., Bonnycastle, L. L., Brambilla, P., Burnett, M. S., Cesana, G., Dimitriou, M., Doney, A. S. F., Döring, A., Elliott, P., Epstein, S. E., Eyjolfsson, G. I., Gigante, B., Goodarzi, M. O., Grallert, H., Gravito, M. L., Groves, C. J., Hallmans, G., Hartikainen, A.-L., Hayward, C., Hernandez, D., Hicks, A. A., Holm, H., Hung, Y.-J., Illig, T., 
Jones, M. R., Kaleebu, P., Kastelein, J. J. P., Khaw, K.-T., Kim, E., Klopp, N., Komulainen, P., Kumari, M., Langenberg, C., Lehtimäki, T., Lin, S.-Y., Lindström, J., Loos, R. J. F., Mach, F., McArdle, W. L., Meisinger, C., Mitchell, B. D., Müller, G., Nagaraja, R., Narisu, N., Nieminen, T. V. M., Nsubuga, R. N., Olafsson, I., Ong, K. K., Palotie, A., Papamarkou, T., Pomilla, C., Pouta, A., Rader, D. J., Reilly, M. P., Ridker, P. M., Rivadeneira, F., Rudan, I., Ruokonen, A., Samani, N., Scharnagl, H., Seeley, J., Silander, K., Stancáková, A., Stirrups, K., Swift, A. J., Tiret, L., Uitterlinden, A. G., van Pelt, L. J., Vedantam, S., Wainwright, N., Wijmenga, C., Wild, S. H., Willemsen, G., Wilsgaard, T., Wilson, J. F., Young, E. H., Zhao, J. H., Adair, L. S., Arveiler, D., Assimes, T. L., Bandinelli, S., Bennett, F., Bochud, M., Boehm, B. O., Boomsma, D. I., Borecki, I. B., Bornstein, S. R., Bovet, P., Burnier, M., Campbell, H., Chakravarti, A., Chambers, J. C., Chen, Y.-D. I., Collins, F. S., Cooper, R. S., Danesh, J., Dedoussis, G., de Faire, U., Feranil, A. B., Ferrières, J., Ferrucci, L., Freimer, N. B., Gieger, C., Groop, L. C., Gudnason, V., Gyllensten, U., Hamsten, A., Harris, T. B., Hingorani, A., Hirschhorn, J. N., Hofman, A., Hovingh, G. K., Hsiung, C. A., Humphries, S. E., Hunt, S. C., Hveem, K., Iribarren, C., Järvelin, M.-R., Jula, A., Kähönen, M., Kaprio, J., Kesäniemi, A., Kivimaki, M., Kooner, J. S., Koudstaal, P. J., Krauss, R. M., Kuh, D., Kuusisto, J., Kyvik, K. O., Laakso, M., Lakka, T. A., Lind, L., Lindgren, C. M., Martin, N. G., März, W., McCarthy, M. I., McKenzie, C. A., Meneton, P., Metspalu, A., Moilanen, L., Morris, A. D., Munroe, P. B., Njølstad, I., Pedersen, N. L., Power, C., Pramstaller, P. P., Price, J. F., Psaty, B. M., Quertermous, T., Rauramaa, R., Saleheen, D., Salomaa, V., Sanghera, D. K., Saramies, J., Schwarz, P. E. H., Sheu, W. H.-H., Shuldiner, A. R., Siegbahn, A., Spector, T. D., Stefansson, K., Strachan, D. P., Tayo, B. O., Tremoli, E., Tuomilehto, J., Uusitupa, M., van Duijn, C. M., Vollenweider, P., Wallentin, L., Wareham, N. J., Whitfield, J. B., Wolffenbuttel, B. H. R., Ordovas, J. M., Boerwinkle, E., Palmer, C. D. C. N. A., Thorsteinsdottir, U., Chasman, D. I., Rotter, J. I., Franks, P. W., Ripatti, S., Cupples, L. A., Sandhu, M. S., Rich, S. S., Boehnke, M., Deloukas, P., Kathiresan, S., Mohlke, K. L., Ingelsson, E., and Abecasis, G. R. (2013). Discovery and refinement of loci associated with lipid levels. Nature genetics, 45(11):1274-83.

Wojcik, G., Graff, M., Nishimura, K. K., Tao, R., Haessler, J., Gignoux, C. R., Highland, H. M., Patel, Y. M., Sorokin, E. P., Avery, C. L., Belbin, G. M., Bien, S. A., Cheng, I., Hodonsky, C. J., Huckins, L. M., Jeff, J., Justice, A. E., Kocarnik, J. M., Lim, U., Lin, B. M., Lu, Y., Nelson, S. C., Park, S.-S. L., Preuss, M. H., Richard, M. A., Schurmann, C., Setiawan, V. W., Vahi, K., Vishnu, A., Verbanck, M., Walker, R., Young, K. L., Zubair, N., Ambite, J. L., Boerwinkle, E., Bottinger, E., Bustamante, C. D., Caberto, C., Conomos, M. P., Deelman, E., Do, R., Doheny, K., Fernandez-Rhodes, L., Fornage, M., Heiss, G., Hindorff, L. A., Jackson, R. D., James, R., Laurie, C. A., Laurie, C. C., Li, Y., Lin, D.-Y., Nadkarni, G., Pooler, L. C., Reiner, A. P., Romm, J., Sabati, C., Sheng, X., Stahl, E. A., Stram, D. O., Thornton, T. A., Wassel, C. L., Wilkens, L. R., Yoneyama, S., Buyske, S., Haiman, C., Kooperberg, C., Le Marchand, L., Loos, R. J., Matise, T. C., North, K. E., Peters, U., Kenny, E. E., and Carlson, C. S. (2017). Genetic Diversity Turns a New PAGE in Our Understanding of Complex Traits. bioRxiv, pages 1-20.

Wu, Y., Marvelle, A. F., Li, J., Croteau-Chonka, D. C., Feranil, A. B., Kuzawa, C. W., Li, Y., Adair, L. S., and Mohlke, K. L. (2013). Genetic association with lipids in Filipinos: waist circumference modifies an APOA5 effect on triglyceride levels. J Lipid Res, 54(11):3198-3205.

Xiao, Z., Wang, J., Chen, W., Wang, P., Zeng, H., and Chen, W. (2012). Association studies of several cholesterol-related genes (ABCA1, CETP and LIPC) with serum lipids and risk of Alzheimer's disease. Lipids in Health and Disease, 11(1):163.

Yang, J., Ferreira, T., Morris, A. P., Medland, S. E., Madden, P. A., Heath, A. C., Martin, N. G., 
Montgomery, G. W., Weedon, M. N., Loos, R. J., et al. (2012). Conditional and joint multiple-snp analysis of gwas summary statistics identifies additional variants influencing complex traits. Nature genetics, 44(4):369-375.

Yang, J., Lee, S. H., Goddard, M. E., and Visscher, P. M. (2011). GCTA: A tool for genome-wide complex trait analysis. American Journal of Human Genetics, 88(1):76-82.

Zhou, L., He, M., Mo, Z., Wu, C., Yang, H., Yu, D., Yang, X., Zhang, X., Wang, Y., Sun, J., Gao, Y., Tan, A., He, Y., Zhang, H., Qin, X., Zhu, J., Li, H., Lin, X., Zhu, J., Min, X., Lang, M., Li, D., Zhai, K., Chang, J., Tan, W., Yuan, J., Chen, W., Wang, Y., Wei, S., Miao, X., Wang, F., Fang, W., Liang, Y., Deng, Q., Dai, X., Lin, D., Huang, S., Guo, H., Lilly Zheng, S., Xu, J., Lin, D., Hu, F. B., and Wu, T. (2013). A genome wide association study identifies common variants associated with lipid levels in the Chinese population. PLoS One, 8(12):e82420.

Zhou, X. (2017). A Unified Framework for Variance Component Estimation with Summary Statistics in Genome-wide Association Studies. bioRxiv, pages 1-26.

Zhou, X. and Stephens, M. (2012). Genome-wide efficient mixed-model analysis for association studies. Nature Genetics, 44(7):821-824.

Zhu, Y., Zhang, D., Zhou, D., Li, Z., Li, Z., Fang, L., Yang, M., Shan, Z., Li, H., Chen, J., Zhou, X., Ye, W., Yu, S., Li, H., Cai, L., Liu, C., Zhang, J., Wang, L., Lai, Y., Ruan, L., Sun, Z., Zhang, S., Wang, H., Liu, Y., Xu, Y., Ling, J., Xu, C., Zhang, Y., Lv, D., Yuan, Z., Zhang, J., Zhang, Y., Shi, Y., and Lai, M. (2017). Susceptibility loci for metabolic syndrome and metabolic components identified in Han Chinese: a multi-stage genome-wide association study. Journal of Cellular and Molecular Medicine, 21(6):1106-1116. 